CHAPTER SIX

\title{
THE HEIDELBERG CHURCH DISCIPLINE CONTROVERSY
}

\begin{abstract}
To one of those churches which lived in most peaceable sort, and abounded as well with men for their learning in other professions singular, as also with divines whose equals were not elsewhere to be found, a Church ordered by Gualther's discipline, and not by that which Geneva adoreth: unto this church, the Church of Heidelberg, there cometh one who craving leave to dispute publicly defendeth with open disdain of their government, that To a minister with his Eldership power is given by the law of God to excommunicate whomsoever, yea even kings and princes themselves. Here were the seeds sown of that controversy which sprang up between Beza and Erastus about the matter of excommunication....

Richard Hooker, Of the Laws of Ecclesiastical Polity.
\end{abstract}

Richard Hooker, no sympathizer of Theodore Beza and the Genevan mode of discipline, correctly identified the Palatinate as the scene of one of the most bitter intramural confrontations in the history of Reformed Protestantism. The controversy had perhaps been looming since 1562, and with a strong disciplinist party dominating the church council with ready access to the prince, naturally Olevianus and his allies desired to implement what they considered to be a more complete form of church discipline. Olevianus wanted to create an independent consistory which would place control over the discipline of moral offenses in the hands of a joint lay/clerical body. The key notion here was to renew authentic Christian discipline independent of state control on a New Testament model. Fundamentally it was an effort to change who controlled discipline, but the Calvinist church leaders also envisioned a more proactive disciplinary regime than that which was currently in effect in Heidelberg. As theologically justified from the Calvinist perspective as their attempt was, their impulse would have fateful consequences for the Palatine church. Unlike the working consensus that existed among the Reformed on the issue of the Lord's Supper, there was no united Reformed opinion on the issue of church discipline. ${ }^{1}$ Thus, seeking to implement a more stringent

${ }^{1}$ On the Zurich Consensus, see Paul Rorem, "Calvin and Bullinger on the Lord's Supper," Lutheran Quarterly 2 (1988): 153-178, 359-384. 
form of discipline inevitably brought the competing traditions of church discipline of the mother Reformed churches of Zurich and Geneva into conflict.

\section{Reformed Theories of Church Discipline}

The coming of the Reformation and the attack on the hierarchical structure of authority of the Western Catholic Church led by the papacy naturally opened wide the question of church-state relations. Many factors coalesced in the early years of the Reformation to greatly favor the authority of the state vis-à-vis the church: pervasive anticlericalism, a sense of historical exploitation by the papacy which was particularly acute in the Holy Roman Empire, and the relatively easy opportunity for the enhancement of political power and fiscal resources offered to both princes and town councils by usurping ecclesiastical jurisdictions. Luther famously challenged political leaders to cross over traditional boundaries of church and state in his Address to the Christian Nobility of the German Nation. Luther then developed his doctrine of the two swords, redefining the areas of competence of church and state. The "Humpty Dumpty" of independent ecclesiastical authority, which could stand toeto-toe with political leaders and whose roots lay in the high medieval Gregorian reform movement, had been definitively shattered, never to be reassembled in such a menacing fashion within a Protestant German state church. While the new order gave explicit recognition to a certain autonomy of the church, by necessity the Lutheran state Reformation was "Erastian" in common parlance, and if ecclesiastical authorities at times were given putative authority to determine proper doctrine, they did so with the sufferance of the magistrate. The 1555 Peace of Augsburg's cuius regio, eius religio had been the de facto rule since the 1520 . Thus, the magisterial Reformation by its very nature had a strong Erastian tendency, though there were many questions left open for future development or elaboration. These questions largely break into three interlocking areas: church-state relations, the structural organization of the church, and church discipline. The early continental Reformation might be described as both adiaphoristic and opportunistic on these fronts; that is, not being too concerned whether the church was effectively controlled by the town council, an oligarchic church council with a general superintendent, or in some cases even retaining bishops, as long as a break from Catholic ecclesiastical authorities took place. 
The perceived need in some quarters for more effective church discipline to facilitate true reform among the unwashed masses further begged the question of larger church structure, which concomitantly brought up the issue of how this structure would relate to the state. Urban reformers from Upper Germany and Switzerland quickly pushed beyond Luther on these crucial issues, as they had done before on the question of the Lord's Supper. Broadly speaking, two competing solutions to these questions arose within the Upper German-Swiss Reformation.

The first Reformed theory of church discipline grew out of the Zwinglian Reformation. Since the Reformation in Zurich was enacted by decision of the town council, from the earliest juncture the civil authorities assumed ecclesiastical jurisdiction. Robert Walton has suggested that this pattern was a natural expression of the church-state relations that had developed before the Reformation. According to Walton, the control over church affairs that the state established during the Reformation "marks the end rather the beginning of the progress." In line with the general pattern of state dominance of the church, the state usurped control over the traditional competence of ecclesiastical courts to police moral infractions after the establishment of the Reformation. While there was some internal debate among the Swiss reformers as to the validity of such overweening state influence, Huldrych Zwingli quite early argued for the scriptural legitimacy of what J. Wayne Baker has labeled the Zurich-Bern "single sphere" model. ${ }^{3}$ This view held that there was no scriptural justification to erect a separate ecclesiastical institution to supervise morals distinct from that of the magistrate in a Christian commonwealth. Indeed Ryan Reeves now argues that Erastus's early supporter Konrad Pellikan weighed in with a reading of Psalm 82 which acknowledged the divine nature of earthly rulers and which had a decisive impact on emerging Protestant political theory in both Zurich and England. ${ }^{4}$ The key figure in

\footnotetext{
2 Robert C. Walton, “The Institutionalization of the Reformation at Zurich," Zwingliana 13 (Heft 8, 1972): 497. The classic English language study is Robert C. Walton's Zwingli's Theocracy (Toronto: University of Toronto Press, 1967).

${ }^{3}$ J. Wayne Baker, "Zwinglianism" in OER, 4:323-327. Baker has written many articles on this topic (See the bibliography), of which the most important for our purposes is "Church Discipline or Civil Punishment: On the Origins of the Reformed Schism, 15281531," Andrews University Studies 23 (1985): 3-18.

${ }^{4}$ Ryan M. Reeves, "'Ye Gods': The Magistrate and Political Obedience in Humanism, Zürich and English Protestantism, c. 1525-1540," Sixteenth Century Studies Conference, Geneva, May 2009.
} 
the articulation of this theory was Zwingli's successor Heinrich Bullinger, who not only upheld the state's right to oversee morals and punish sinners in a Christian society, but also even questioned whether excommunication, in the strict sense of barring sinners from taking communion, was a valid ecclesiastical censure. ${ }^{5}$ Bullinger's Decades or Hausbuch, which was one of the more popular theological compendia of the century, disseminated the basic Zurich concept, if in a somewhat muted fashion. ${ }^{6}$ The third major advocate of the "single sphere" conception of state relations and church discipline was the reformer Wolfgang Musculus, who worked in Augsburg prior to the Interim and ended his distinguished career as the leading minister in Bern, the most powerful Swiss canton. Musculus offered ideas that complemented the Zurich position; for example, that the precedent of the Israelite state in the era of the Davidic monarchy was a fitting analogy for contemporary church-state relations. He had a rather extreme view of the superiority of the divinely sanctioned "magistrate" over the humble "minister" of the church and drew his arguments both from Scripture and nature. ${ }^{7} \mathrm{He}$ also delineated part of Erastus's future line of argumentation in the later Heidelberg debate by asserting that excommunication was a power possessed by the church only "if it lacke

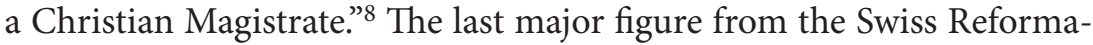
tion to emerge as a vigorous advocate of the Zurich-Bern "single sphere" model was Bullinger's protégé and eventual successor Rudolf Gwalther, whose ideas evolved in dialogue with those of Erastus himself. ${ }^{9}$

${ }^{5}$ See Bullinger's noteworthy letter to Berchtold Haller from July 1531 in Heinrich Bullinger Werke, 2. Abteilung Briefwechsel, ed. Fritz Büsser, et al. (Zurich: Theologischer Verlag, 1972), 1:205-216.

${ }^{6}$ See most recently Torrance Kirby, "The Civil Magistrate and the 'cura religionis': Heinrich Bullinger's prophetical office and the English Reformation," in Heinrich Bullinger (1504-1575): Leben, Denken, Wirkung. Internationaler Bullingerkongress 2004, ed. Emidio Campi and Peter Opitz (Zurich: Theologische Verlag, 2006), 935-950. Bullinger is quite deferential, though not perhaps to the degree as Musculus, to magisterial authority throughout the Decades. Discipline remains under its purview. He does not challenge the concept of excommunication per se, but employs the concept in two primary contexts: one a very negative association of the excessive claims to spiritual authority of the papacy within the Catholic Church and the other as an exclusion from the community, but not explicitly a debarment from the sacraments. Heinrich Bullinger, The Decades of Henry Bullinger, ed. Thomas Harding (Cambridge, 1849).

7 Wolfgang Musculus, Common Places of Christian Religion ... (London, 1563), 1283-1340. See James Thomas Ford, "Wolfgang Musculus on the Office of the Christian Magistrate," ARG 91 (2000): 149-167.

${ }^{8}$ Musculus, Commonplaces, 636.

9 Wesel-Roth, Thomas Erastus, 102-107. 
The Zurich Reformation also created two institutions to deal with issues of discipline and regulation of clerical affairs, which had a broad impact on the Upper German-Swiss Reformation. The "synod" was a biannual gathering of clergy more analogous perhaps to the Venerable Company of Pastors of Geneva than what is conventionally termed a "synod" in much of the Reformed world. Policing the clergy per se was the chief object of this body. ${ }^{10}$ The institution which had broader jurisdiction over the morals of the community at large was the "marriage court" (Ehegericht), which had been established in 1525. This institution was the successor of the court of the bishop of Constance, who had been the ecclesiastical overlord of the Zurich commune. Though this institution was a marriage court by name, it soon expanded its jurisdiction so that it became in effect a wide ranging morals court. Clerics played an active role in its proceedings, but it was essentially a civil institution dominated by the magistrate. While the Genevan Consistory has received much more attention from historians, and likewise, more negative press, the Zurich marriage court could also be petty and vindictive. ${ }^{11}$ Ministerial influence was so strong in the marriage court and on state policy in general in the late 1520 s that many observers have marked the "theocratic" tendencies of the Zurich Reformation. The relative influence of clerics lessened after the death of Zwingli, and the state directly controlled the marriage court and oversaw the operation of the synods. The clergy had an advisory or "prophetic" role, which of course could be substantial considering the deep penetration of spiritual concerns in sixteenth-century social life and politics. Analogous institutions were created in cities such as Bern, Basel, and Schaffhausen. ${ }^{12}$

${ }^{10}$ See Pamela Biel, Doorkeepers at the House of Righteousness. Heinrich Bullinger and the Zürich Clergy 1535-1575 [ZBRG 15] (Bern: Peter Lang, 1991), 207-203 (with a translation of the 1532 synod mandate) and Bruce Gordon, Clerical Discipline and the Rural Reformation: The Synod in Zürich, 1532-1580 [ZBRG 16] (Bern: Peter Lang, 1992), passim.

${ }^{11}$ For example, Norman Birnbaum almost makes the marriage court look like a forerunner of a revolutionary tribunal: "Zwingli used it to terrorise the political opposition (espionage and denunciation were some of its techniques), as well as to punish sinners and encourage, if that is the word, the morally weak." "The Zwinglian Reformation in Zürich," Past and Present 15 (1959): 35.

12 Walther Köhler, Zürcher Ehegericht und Genfer Konsistorium, vol. 1, Das Zürcher Ehegericht und seine Auswirkung in der deutschen Schweiz zur Zeit Zwinglis [Quellen und Abhandlungen zur schweizerischen Reformationsgeschichte 7] (Leipzig: N. Heinsius Nachfolger, 1932); Walton, Zwingli's Theocracy; J. Wayne Baker, "Calvin's Discipline and the Early Reformed Tradition: Bullinger and Calvin," in Calviniana: Ideas and Influence of Jean Calvin [SCE\&S 10], ed. Robert V. Schnucker (Kirksville, Mo., 1988), 
This model had much to recommend itself to the leading Swiss cantons. It apparently had strong biblical sanction by analogy with the respective roles of church and state in the Hebrew Scriptures. Perhaps more critically, however, this state-dominated model was threatened by an alternative sectarian vision of the church as a gathered community drawn out of society that should administer its own discipline. Thus, in their encounter with the Anabaptists, the Swiss Reformed had a very early negative exposure to a "precisianist" group that deployed excommunication or the ban to purify itself. Since the Swiss Reformed viewed the Anabaptists' gathered church as a malevolent and seditious threat to the conventional notion of the city as a Christian community, the constructive features of their program, however strong their biblical rationale, tended to have a negative association. Finally, from the state perspective it seemed clerics had exercised too much influence over society and politics at large in the tumultuous decade which culminated in the Second Kappel War (1531). With Zwingli's passing on the battlefield, his able successor Bullinger had a difficult task even reasserting a prophetic advisory role for the clergy in Swiss politics. State dominance over the church and exclusive jurisdiction over moral infractions became the rule in the German-speaking Reformed Swiss Cantons.

The Calvinist-Reformed tradition, however, had initiated a program of church discipline along different lines. The central concept of this system was to give authority over church discipline to an assembly of elders and ministers working in concert-the consistory. Johannes Oecolampadius, the reformer of Basel and Zwingli's close collaborator, first propounded this theory in the late 1520 . Martin Bucer was the most important early advocate of more effectual church discipline-even regarding it as a mark of the true church - though he was never given full sanction to implement a more rigorous model with independent church control over excommunication in Strasbourg. Bucer was nevertheless a critical influence on John Calvin, who became the chief advocate of consistorial dis-

cipline to the larger Reformed world. ${ }^{13}$ Calvin viewed exercising power over excommunication as critical to the church's mandate to purify itself.

107-119; Hans Ulrich Bächtold, Heinrich Bullinger vor dem Rat: Zur Gestaltung und Verwaltung des Zurcher Staatswesens in den Jahren 1531-1575 [ZBRG 12] (Bern: Peter Lang, 1982).

${ }^{13}$ See Amy Nelson Burnett, The Yoke of Christ: Martin Bucer and Christian Discipline [SCE\&S 26] (Kirksville, Mo., 1994). 
In fact, his insistence on an independent sphere of ecclesiastical authority was one of the major factors that led to his expulsion from Geneva in $1538 .{ }^{14}$ Such a "presbyterial" order mandated a clear separation of the spheres of competence of church and the civil authority, but Calvin and his followers hoped that the two spheres would work in collaboration rather than conflict. Calvin had to struggle for much of his time in Geneva to make his vision a reality, and it was only after the Servetus trial and the exile of prominent members of the Libertine faction in 1555 that Calvin's allies were able to fully implement their program. Without this autonomous, self-regulating feature, Calvinists considered the church's integrity threatened. ${ }^{15}$

What did this consistorial-presbyterial model look like on the ground? First, a word about vocabulary. The word "consistory" traditionally referred to a church court whereas "presbytery" denoted a gathering of elders-though "presbyter," of course, was also the etymological root for "priest." Although the words "consistory" and "presbytery" might be used interchangeably, they eventually came to denote different levels of governance within Reformed church polity. Ironically, Calvin and Beza became prime exponents of "presbyterian" or "presbyterial" church polity in a community that did not formally have a body bearing that title. ${ }^{16}$ What was essential in their views was that a body of elders, in Geneva the consistory, exercise proper authority over matters which pertained to the church-especially oversight of matters of morals and belief. In the case of Geneva, the consistory was a city-wide institution, rather than being based on an individual parish, which also had jurisdiction over the outlying rural districts. The consistory in Geneva was a joint lay-ecclesiastical body, and all members of the Venerable Company of Pastors were ex officio members of the consistory, though they did not always attend.

14 William G. Naphy, Calvin and the Consolidation of the Genevan Reformation (1994, repr. Lexington: Westminster John Knox Press, 2003) 28-33; Bruening, Calvinism's First Battleground, 163-165.

15 Pelikan, The Christian Tradition, 4:215-216; Baker, "Calvin's Discipline and the Early Reformed Tradition," 108-111. For Calvinist discipline in general, see Philip Benedict, Christ's Churches Purely Reformed: A Social History of Calvinism (New Haven: Yale UP, 2002), 460-489.

16 I intentionally employ "presbyterial" instead of "Presbyterian" in this chapter to emphasize the role of elders in church polity rather than a direct identification with a modern denomination. In the French-Dutch Calvinist tradition, the term for the local oversight body is "consistory," the regional body a "classis," and the national or international gathering a "synod." For Presbyterians the structure would run "session," "presbytery," and regional "synod," with a "general assembly" at the highest level. 
While the lay members were appointed by the town council, the pastors influenced the selection of suitable elders during the institution's heyday in the second half of the sixteenth century. A layman, one of the leading syndics or magistrates of the city, presided over the Genevan consistory. Individuals who were cited to appear before the consistory after a brief inquest and counseling session might endure sanctions including admonishment, required attendance at sermons, humiliating acts of public penance, and finally excommunication. The most common form of excommunication was more of a short-term suspension from taking part in the Lord's Supper. Individuals who were unrepentant or unwilling to submit to the authority of the consistory might suffer the major ban (formal excommunication), and thus be cut off from church life. While in theory the Geneva Consistory was a non-coercive institution to which people voluntarily submitted themselves, the social stigma of excommunication was great and bore with it great civil liabilities, such as the exclusion from participation in baptism and the prohibition from entering a Christian marriage.

While the Genevan consistory in combination with the preaching and catechetical ministry of the pastors seems to have done a superb job over a few decades in inculcating a Reformed vision of the Christian faith in Geneva, this success came at a price, the chief burden of which was a high degree of prying into areas of life that modern Westerners would consider private. E. William Monter has calculated that one in fifteen Genevans were called before the consistory annually in the period of the 1560 s and 1570 s and that at its highpoint the consistory excommunicated nearly three hundred people per year. ${ }^{17}$ Robert Kingdon, the leading modern authority on Calvin and the Genevan Reformation, has bluntly concluded that the consistory was a "remarkably intrusive institution." ${ }^{18}$ However, for many sixteenth-century observers the consistory's value in effecting a genuine reformation of morals served as a tremendous confirmation of the theology behind it. While the system had its detractors (some of whom we will soon meet), the success of consistorial discipline in turning Geneva into a Godly community was one of its chief attractions to sixteenth-century Protestants.

17 E. William Monter, “The Consistory of Geneva, 1559-1569," Bibliothèque d'humanisme et de la renaissance 38 (1976), 84.

18 Robert Kingdon, "The Genevan Consistory in the Time of Calvin," in Calvinism in Europe, 1540-1620, ed. Andrew Pettegree et al. (Cambridge: Cambridge UP, 1994), 22 and 34. See Robert Kingdon, et al. eds., Registers of the Consistory of Geneva in the Time of Calvin, vol. 1, 1542-1544 (Grand Rapids, Eerdmans, 2000). 
While Geneva became the example of a successfully reformed community, it was easier to export the consistorial model than it was to fully replicate the Genevan experience. Geneva represented a unique political and sociological laboratory with its unusual position as a quasiindependent city-state allied to the Swiss confederacy. Geneva's singular religious climate turned it into a Mecca for Protestant refugees at mid-century, and the flood of refugees in turn further transformed the Genevan Reformation and empowered the Calvinist church leaders. Geneva's peculiar model of ecclesial organization with auctoritas in church matters lying with the Venerable Company of Pastors could not easily be reproduced: Geneva was distinct in the size of the community, the quality of the ministerial staff, but even more importantly in possessing Calvin's charismatic leadership. A system of discipline developed along parallel lines in the French church "under the cross," due in part to the direct involvement of the Venerable Company. Of course, the practical functioning of the system varied from community to community, and, not surprisingly, Huguenot lords were not nearly as eager to erect such a system of consistorial discipline as were bourgeois town councils. The Genevan Company of Pastors remained a resource of theological authority and a clearinghouse of ministerial candidates for the French churches-in effect, an ersatz papal curia. In general these local consistories were dominated by influential lay bourgeoisie and tended to be more moderate in their exercise of discipline than the Genevan consistory in the 1560 s and 1570 s. $^{19}$

The church's ability to administer discipline was seen by most later Calvinists as a distinctive mark of a true church (notae ecclesiae), alongside preaching the gospel and the correct administration of the sacraments. ${ }^{20}$ While Calvin was likely the century's most forceful advocate of effective church discipline, he did not include it among the notae ecclesiae. Some scholars have attempted to distinguish between Calvin, who at these junctures is seen to have retained a measure of his Erasmian humanist ethos, and his more hard-line followers who pushed

19 Raymond Mentzer, "Marking the Taboo: Excommunication in French Reformed Churches," Raymond Mentzer, ed., Sin and the Calvinists: Morals Control and the Consistory in the Reformed Tradition [SCE\&S 32] (Kirksville, Mo., 1994), 97-128; Glenn S. Sunshine, Reforming French Protestantism: The Development of Huguenot Ecclesiastical Institutions, 1557-1572 [SCE\&S 66] (Kirksville, Mo.: Truman State UP, 2003), 121142.

${ }^{20}$ E.g., article 29 of the Belgic Confession of 1561. 
his formulations to uncomfortable extremes, whether on predestination or church discipline, without Calvin's pastoral heart. The theological gulf between Calvin and his rigorist followers, whether they be labeled "Gnesio-Calvinists," "disciplinists," or "precisianists," is not that great. ${ }^{21}$ On the one hand, if Calvin did not recognize the proper exercise of church discipline as a fully fledged mark of an authentic church, he did see it as a mandatory adjunct of the proper administration of the sacraments. Therefore, the tendency of later theologians and creeds to add church discipline to the marks of the church would appear to be a natural extension of Calvin's thought. On the other hand, going beyond Calvin and turning this discipline into a nota ecclesiae, was a stone of offense to other Protestants who did not practice as rigorous a discipline as the Genevans or the Calvinist church "under the cross." Thus, the expression "Gnesio-Calvinist" has some explanatory utility in marking a group whose rigorous devotion to a particular vision of authentic Calvinism alienated others within the Reformed movement. This fissure is analogous in part to the division within the Lutheran community between "Gnesio-Lutherans" and their moderate or Philippist antagonists. In both cases the "Gnesio" faction largely succeeded in assuming control over the tradition and redefining its boundaries.

There had been earlier skirmishes within the Reformed communion on the issue of church discipline. One of the early flash-points was in the Pays de Vaud, a French-speaking territory under Bernese control, where Calvin advocated the Genevan position from abroad and his ally Pierre Viret vigorously worked from within to establish consistorial discipline. The Bernese authorities who ultimately controlled the religious policy of the Vaud would tolerate consistories, but steadfastly refused to grant the nascent Calvinist church organization independent authority over excommunication. They were fortified in their rejection of a Genevan model of discipline by the arrival in Bern of Musculus, who advocated the classic Swiss-German position that Erastus would later espouse. The Zurich church naturally weighed in on this controversy as well, and

${ }^{21}$ I borrow the expression "Gnesio-Calvinist" from Heiko A. Oberman, The Two Reformations: The Journey from the Last Days to the New World, ed. Donald Weinstein (New Haven: Yale UP, 2003), 135. Theodore Dwight Bozeman has recently illuminated this tendency in Anglo-American Reformed Protestantism in The Precisianist Strain: Disciplinary Religion and Antinomian Backlash in Puritanism to 1638 (Chapel Hill: University of North Carolina Press, 2004). 
while it by no means supported Viret's drive to establish consistorial discipline, the most recent analysis of the conflict has depicted Bullinger's primary role in the conflict as that of a peacemaker. The final result of this conflict was the mass exodus of Viret and the other Calvinist personnel in 1559 after they failed to establish consistorial discipline. ${ }^{22}$ Before the Heidelberg controversy, the French Reformed church had also been racked by strife on this question of church discipline and its concomitant structural issues. Though he did not attack church discipline per se, Jean Morély argued that the final source of authority should be the local church-though perhaps conceived more on a diocesan rather than strictly a congregational model - and implied that the conventional Calvinist disciplinary model placed too much authority in the hands of the clerically dominated consistory. He also faulted the Calvinist system for withholding a role for the magistrate in discipline. In a predictable twist, Morély's opponents in Geneva arranged his excommunication for his opposition to the Calvinist vision of discipline. Petrus Ramus championed Morély's vision of ecclesiastical organization at the synod of La Rochelle in 1571, though their views were again repudiated. ${ }^{23}$ The issue of church discipline would later be the source of strife in both the Netherlands and Britain. The Heidelberg controversy was thus not an isolated event but one episode in a series of controversies over church discipline.

\section{George Withers and the Outbreak of the Controversy}

The rivalry between disciplinist and anti-disciplinist factions in the Palatinate intensified until open conflict erupted in June of 1568. Like the earlier controversy over the Lord's Supper, the promotion of a foreign doctoral student opened the dispute. The English cleric George With-

\footnotetext{
22 Bruening, Calvinism's First Battleground, 253-255.

23 On Jean Morély see Philippe Denis and Jean Rott, Jean Morély (ca. 1524 - ca. 1594) et l'utopie d'une démocratie dans l'Eglise [THR 278] (Geneva: Droz, 1993); Robert M. Kingdon, Geneva and the Consolidation of the French Protestant Movement 1564-1572 [THR 92] (Geneva: Droz, 1967); Michael Graham, The Uses of Reform: "Godly Discipline" and Popular Behavior in Scotland and Beyond, 1560-1610 [SMRT 58] (Leiden: Brill, 1996), 320-322; Sunshine, Reforming French Protestantism. On Ramus's role in these developments, see James Veazie Skalnik, Ramus and Reform: University and Church at the End of the Renaissance [SCE\&S 60] (Kirksville, Mo.: Truman State UP, 2002).
} 
ers (1540-1604) advocated a more thorough Reformation than that espoused by the church hierarchy under Elizabeth I. Like his Puritan brethren, he resented such "Romish" vestiges as clerical vestments and stained glass, but also desired the erection of a genuinely Reformed system of church discipline. During the Vestiarian Controversy of 15641566, Withers had refused to wear the "square cap" prescribed by the 1559 Prayer Book. Withers was one of the representatives of the emerging Puritan party who traveled abroad in an effort to influence church leaders in Zurich, Geneva, and beyond on its behalf. ${ }^{24}$ While the party received a sympathetic hearing in Geneva, Bullinger and Gwalther eventually came to see Withers and his ilk as unwelcome troublemakers. ${ }^{25} \mathrm{~A}$ long, undated petition from Withers to Elector Frederick III has survived in which he outlined the evolution of the religious scene in England from King Henry to the present. He asserted that Satan was now undermining the cause of true Reformation through the machinations of careerist clergy who were bowing to the whims of the queen and her lackey bishops. Withers was not only dismayed by the persistence of traditional worship forms, he also lamented that a more biblical version of church discipline had not been installed in England. In line with other Gnesio-Calvinists, Withers asserted in his petition: "For there being three chief parts of the church, wholesome doctrine, the pure administration of the sacraments, and a rightly constituted ministry, which part also includes a vigorous discipline." In England, alternatively, "The ministry is in fact nothing at all, nor is there any discipline." ${ }^{26}$ As part of this larger campaign on behalf of the Puritan party, Withers had arrived in Heidelberg by the spring of 1568 and apparently sought both to advance his scholarly pedigree and to create a little controversy. ${ }^{27}$ While he was not able to influence the elector to champion the cause of further reformation with the queen directly, Withers secured a long, impassioned plea on the English Puritans' behalf from

${ }^{24}$ Brett Usher and John Craig, "Withers, George (bap. 1540, d. 1605)," in Oxford Dictionary of National Biography (Oxford: Oxford UP, 2004); Laquita M. Higgs, Godliness and Governance in Tudor Colchester (Ann Arbor: University of Michigan Press, 1998), 204.

${ }^{25}$ For Zurich's and particularly Gwalther's uncomfortable position between the English factions during the Vestiarian controversy, see Patrick Collinson, The Elizabethan Puritan Movement (Berkeley: University of California Press, 1967), 79-83.

26 "George Withers to the Prince Elector Palatine," in Hastings Robinson, trans., The Zurich Letters (Second Series) (Cambridge, 1845), 156-164 (no. 62).

27 Withers was inscribed on the Heidelberg matriculation list on March 22, 1568. Toepke, Die Matrikel der Universität Heidelberg, 2:45. 
the pen of the university theologian Girolamo Zanchi which decried the Satanic temptations of Popish vestments. ${ }^{28}$

Along these lines, Withers's original intention seems to have been to defend theses on clerical vestments, which the Heidelberg theology faculty wisely disallowed, as it did not want to be seen as fomenting discord within the English church. The alternative plan to defend theses on church discipline was equally incendiary, as events in Heidelberg would later prove. Unfortunately, the extant sources for the early stages of this controversy are rather thin. It does not seem possible to answer the most fundamental question about Withers's theses, viz., who was the driving force behind them. Unlike modern doctoral dissertations and theses, the actual defense of the theses was the crucial step in earning the degree rather than the original composition of the text. Frequently the theses proposed for attaining academic degrees would have been composed by the sponsoring professor rather than the person pursuing the degree. In this case, no background information has been uncovered which shows whether Withers himself or the sponsoring professor Pierre Boquin actually composed the theses. A third option would be that Withers was encouraged by leading figures within the Palatine church such as Olevianus, Dathenus, or Zuleger to defend these theses as a test balloon. Since there is no conflict in seeing all three entities as playing some role in arranging Withers's promotion, it is not necessary to single one party out: all were evidently on board.

The defense of the theses commenced on June 10 and continued for some days, though the extant sources do not fully illuminate this stage of the controversy. The theses contained a couple of provocative assertions which may have seemed rather commonplace among French or Dutch Protestants, but which were quite inflammatory in context of a German state church. Withers upheld the divine right of presbyterial rule, and, granting a clerically led presbytery power over excommunication, even maintained that the presbytery ought to have power to excommunicate the prince. Furthermore, he implied that presbyterial discipline was a mark of the true church, alongside preaching the word and administering the sacraments. ${ }^{29}$ Erastus does not appear to have been directly involved

28 "Hierome Zanchius to Queen Elizabeth," Heidelberg, Sept. 10, 1571, The Zurich Letters (Second Series), appendix 1, 339-353.

29 Theses 12 and 13 are printed in Ursinus, Opera Theologica, ed. Quirinus Reuter (Heidelberg: Johann Lancellot, 1612), 3:801; reprinted in Alting, Historia de ecclesiis Palatinis, 101 (ch. 54). "Thesis XII: Ad sinceram verbi Divini praedicationem \& legitimam Sacramentorum administrationem, oportet in Ecclesia gubernationis vigere officium. 
at this juncture. When reminiscing about the controversy many years later, Erastus would recount that he had been preoccupied with treating the sick and wounded from Johann Casimir's recent military campaign in France when the controversy erupted and thus had been unable to take part in the debate. Alting reports that Adam Neuser, a popular preacher of the Peterskirche, represented the nascent "anti-disciplinist" side in opposing Withers in the theses defense. Despite the opposition, Withers was subsequently awarded his degree on June 20. Neither his sponsor Boquin nor Erastus himself regarded the fact that Withers had defended controversial theological theses as being out of order. ${ }^{30}$ Unfortunately for the Palatinate, Withers's theses became the impetus in which the passionate disagreement regarding church discipline became a matter of public discussion, among both university students and the Palatine clergy.

The summer and fall of 1568 would prove to be the most heated public phase of the Heidelberg church discipline controversy. Erastus's first letter to Bullinger after the start of the controversy in June did not even mention the quarrel but did ominously report that it was not currently possible to print Bullinger's work in Heidelberg. ${ }^{31}$ Erastus did not inform Bullinger about how a "certain Englishman" had stirred up a tempest in Heidelberg until August, and he commented that he saw "neophytes and adolescents" behind it. ${ }^{32}$ Sensing the disciplinary fervor in the air,

Thes. XIII. Officium autem hoc voco, ut Ministri cum Presbyterio quovis peccantes (etiam Principes) arguendi, increpandi, excommunicandi, reliquaque ad disciplinam Ecclesiasticam pertinentia peragendi facultatem habeant \& exerceant." See also Sudhoff, C. Olevianus und Z. Ursinus, 343; Bonnard, Thomas Éraste, 45-48.

${ }^{30}$ Heidelberg, Universitätsarchiv Heidelberg, MS A-16o/ 9, fols. $75^{\mathrm{r}}-75^{\mathrm{v}}$; Erastus, Explicatio gravissimae quaestionis, [A $6^{\mathrm{r}}$ ]; Alting, Historia de ecclesiis Palatinis, 102 (ch. 54); Wesel-Roth, Thomas Erastus, 53-54. Alternatively, Alting has Erastus protesting along with Neuser that not enough time had been given for the opposing views. Erastus fairly explicitly says that he did not take part in the disputation ("Itaque ne ego aliquid movere aliquid, nec propter negotia, interesse potui.") Neuser's participation is not mentioned in Boquin's account in the university protocols but is perhaps likely.

${ }^{31}$ Erastus to Bullinger, July 18, [1568], StAZ, E II 361, fol. 35: "Librum tuum hic imprimi impossibile est. Valde cupiunt, qui eum viderunt, etiam Ursinus, excudi. Ipse quoque te oro, ut operam des, quo vel à nundinis statim vel etiam ante imprimatur Basilienses iuuare te poterunt, puto."

${ }^{32}$ Erastus to Bullinger, August 21, [1568], Zurich, Staatsarchiv des Kantons Zürich, MS E I 25, 8, fol. 52. "Venit ad nos huc nuper (tibi soli dico) Anglus quidam, ut Doct[or] crearetur, et proposuit Theses ad disputandum, in quibus oportere scribit Disciplinam in omni vera Ecclesia vigere, qua ministri cum presbyterio quosvis peccantes, etiam Principes excommunicent. Peperit ea res turbas et dissensiones, ac verendum est, ne gliscat odium conceptum, serpatque longius. Quocirca commentarium ipse mihi ea 
Erastus responded in the summer of 1568 with 103 theses on the topic of church discipline that circulated freely among the Heidelberg students. Rather naturally, a conflict between the Zurich and Geneva visions of church discipline drew in the interests of the respective home churches, and both parties would attempt to influence the outcome of events in the Palatinate. The conflict would severely strain relations between the Zurich and Genevan Reformers, though ultimately the restraint of Bullinger and Beza mollified the impact of this bitter disagreement. The following section will offer a brief analysis of Erastus's critique of the Calvinist vision of church discipline before returning to a narrative of the events in Heidelberg.

\section{The Explicatio gravissimae quaestionis}

The most famous document to come out of the Heidelberg controversy over church discipline was Erastus's treatise on excommunication, the Explicatio gravissimae quaestionis. This work had a rather twisted redaction history. The actual Explicatio consisted of Erastus's 75 theses on excommunication, distilled from his original 103 theses written sometime in 1569. The theses made up the first quarter of the book, which was published posthumously (discussed below in the epilogue). The published edition also contained Erastus's lengthy rebuttal of Beza entitled Confirmatio thesium. Besides these materials, the book also printed assorted letters of Bullinger and others relating to the controversy. Further complicating the redaction history is the existence of an unpublished 1568 manuscript by Bullinger bearing the title Tractatus de Excommunicatione which shares some material with Erastus's Explicatio gravissimae quaestionis. I follow Baker in assuming that the last parts of Bullinger's Tractatus de Excommunicatione were probably culled from Erastus's work. ${ }^{33}$

de re conscripsi ferè; in quo, quid de hac re sentiendum, sit; perspicuè et ex verbo dei validissime ostendere, me puto. Cum perfecero exemplum tibi mittam. Una verbo dicam, quicquid de ea dicatur, non poterit ea forma in nostras Ecclesias sine certa ruina induci, quam Neophyti quicquid et Adolescentuli urgent, suaeque amibitionis causa cum perniciae Ecclesiae stabilire exoptant. Sed D[omi]n[u]s ista curabit."

33 J. Wayne Baker, "In Defense of Magisterial Discipline: Bullinger's 'Tractatus de Excommunicatione' of 1568," in Heinrich Bullinger 1504-1575: Gesammelte Aufsätze sum 40o. Todestag $[Z B R G$ 7], 1:141-144. It is likely that Baker's supposition "Indeed the last 
The title of Erastus's treatise focused on the question, "whether excommunication ... is based upon Divine Mandate or is contrived by men." 34 That Erastus had narrowed his topic to precisely excommunication as removal from the sacrament was significant. His Swiss predecessors had used the word excommunication as a synonym for discipline. This usage produced the novelty of a church that practiced "excommunication" (i.e., discipline) without formal excommunication (exclusion from the sacrament). ${ }^{35}$ While Erastus used the question of excommunication as a vehicle to address church discipline in general, the heart of the work was focused specifically on whether there was biblical precedent for using access to the sacraments as means of discipline. Erastus did not reject discipline in general or the private responsibility of pastors and laymen to admonish wayward brethren. He even suggested that something like the practice of shunning may be suggested by the Bible. ${ }^{36}$ He could find no justification, however, for the notion that the admission to or refusal of the sacrament had been intended as a disciplinary tool.

Erastus not only rejected the sacraments' putative connection to discipline, he also questioned the church's theoretical power over the disposition of human souls. In the early sections of his treatise, Erastus issued a frontal assault against a millennium of church teaching when he implicitly rejected the power of the keys (potestas clavium). A critical component of the rationale for excommunication was that the visible church possessed the power to "bind and loose" things in heaven. The church's absolution was the word of divine forgiveness; the church's anathema condemned a person for eternity. Erastus rejected this notion by denying any necessary relationship between the invisible and visible churches. Erastus asserted that faith alone was the quality that makes a

nine folios may well be a copy of the entire lost 'Tractatio' of Erastus" (p. 144) is correct. See also Wesel-Roth, Thomas Erastus, 148.

${ }^{34}$ Thomas Erastus, Explicatio Gravissimae Quaestionis utrùm Excommunicatio, quatenùs Religionem intelligentes \& amplexantes, à Sacramentorum usu, propter admissum facinus arcet; mandato nitatur Divino, an excogitata sit ab hominibus ([London: John Wolfe], 1589). Since the Latin version of the work is separated into 75 numbered theses, as are the later English translations, thesis numbers are included in addition to the page numbers. Latin quotations will be given in the notes and the documents (English and Latin) shall be collectively referred to as the Explicatio gravissimae quaestionis. The circumstances surrounding the publication of the treatise are discussed in the epilogue.

${ }^{35}$ Baker, "Church Discipline or Civil Punishment," 13.

${ }^{36}$ Explicatio gravissimae quaestionis, 14-15, 23-24, 61 (theses 31, 37, \& 75). 
person a Christian: "And indeed we are made members of Christ, that is, are joined to the internal and spiritual fellowship of Christ, and the faithful, by that faith alone which works by charity." ${ }^{37}$ Because of this spiritual link to Christ through faith, Erastus maintained that association with the visible church and participation in its sacraments did not possess a necessary relationship to salvation. Since a person might belong to the visible church and not achieve salvation, being rejected from the visible church or cut off from its sacraments did not in itself damn a person because it was impossible for any human being to separate a true believer from Christ. ${ }^{38}$ This was a sentiment shared by both Zwingli and Bullinger that had been earlier espoused by Marsilius of Padua, the great critic of the exalted powers of the medieval papacy. ${ }^{39}$

If participation in the visible church and her sacraments had no necessary relationship to a person's ultimate salvation, one could legitimately ask what role sacraments played. Though Erastus did not repudiate his late Zwinglian understanding of the sacraments as outlined in his earlier Eucharistic works, he placed stress in the Explicatio gravissimae quaestionis on the simple Zwinglian notion that the Lord's Supper served primarily as a commemoration of the death of Christ and thanksgiving for the redemption it achieved. ${ }^{40}$ Erastus argued that personal faith alone remained far more important than participation in the sacrament. One of the reasons Erastus thought the concept of excommunication was wrongheaded was that it seemed to carry the reverse implication that salvation itself was limited to the sacraments. ${ }^{41}$ Erastus thought it sent the wrong signal to forbid someone from participating while at the same time allowing them to attend sermons, since this would seem to suggest that sacraments were superior to preaching of the word. ${ }^{42}$

${ }^{37}$ Ibid., 2 (thesis 4). "Ac membra quidem Christi efficimur, id est, internae spiritualiq; Christi, \& fidelium societati coniungimur, per solam fidem, quae charitatem est efficax."

${ }^{38}$ Ibid., 2-3 (theses 2-4). Zwingli had likewise argued that excommunication did not damn someone per se; rather, it was only a sign of damnation. See Stephens, The Theology of Huldrych Zwingli, 270-274. For a comparative look at the later Eucharistic theologies of Zurich and Geneva, see Rorem, "Calvin and Bullinger on the Lord's Supper."

39 Walton, "Der Streit zwischen Thomas Erastus und Caspar Olevian," 234; Marsilius of Padua, The Defender of the Peace, trans. Alan Gerwirth (New York: Columbia UP, 1965) see vol. 2 , ch. 6 .

${ }^{40}$ Explicatio gravissimae quaestionis, 23-24 (thesis 37).

${ }^{41}$ Ibid., 58-6o (thesis 72).

${ }^{42}$ Ibid., 24-25 (thesis 38). 
Sacraments played only a positive role in Erastus's thought as "incitements and allurements to religion and piety." Unlike his fellow partisans Sylvan and Brunner, who seemed to retreat to a strict memorial interpretation of the sacrament during the controversy over church discipline, Erastus still maintained the efficacy of the sacrament by arguing that "by the frequent use of these ordinances, rather than being deprived of them, people are made better;" whereas, "if men are deprived of this invitation they will never grow better but always worse." ${ }^{43}$ Erastus also maintained that a person can commune to his or her "damnation" if he or she lacks faith. ${ }^{44}$ While solemnity is needed in approaching sacraments to avoid the pitfall of "unworthy" eating, Erastus insisted that Christ taught believers to examine themselves - not one another. ${ }^{45}$ Thus, Erastus would not limit access to the sacraments to Christians though naturally the unbaptized-“Mohammedans and unconverted pagans"- should not be allowed to commune. ${ }^{46}$ Erastus conceived his opposition to the Calvinist disciplinary model as a battle to preserve the liberty of the individual Christian and to defend the exclusively positive function of the sacrament. This particular argument would have a long life among American and English Protestants, both in Stoddardeanism and Latitudinarianism. ${ }^{47}$

Since the sacraments functioned to nurture faith, Erastus argued that it was a cold irony that those who needed them most, manifest sinners, should be deprived of them. Erastus was convinced that the evangelical faith was only beginning to penetrate the hearts of the people in the Palatinate when the controversy over excommunication broke out. Erastus wryly mocked the enthusiasm of the disciplinists for excommunication, "when we neither had men to excommunicate or fit excommunicators; for scarcely a thirtieth part of the people did understand and approve of the reformed religion." ${ }^{48}$ Rather than serving the good

${ }^{43}$ Ibid., 13 (thesis 19). "Sacramenta, incitamenta seu invitamenta esse ad pietatem: Et horum frequenti usu potius, quam privatione homines reddi meliores...."

${ }^{44}$ Ibid., 23-24 (thesis 37).

45 Ibid., 22-23 (thesis 35 ).

46 Ibid., 24-25 (thesis 38 ).

47 See, for example, E. Brooks Holifield, "The Intellectual Sources of Stoddardeanism," The New England Quarterly 45 (1972): 372-392.

${ }^{48}$ Explicatio gravissimae quaestionis, introduction $\left(\mathrm{A}_{4}{ }^{\mathrm{r}}\right)$ : "Mirabar eos tum haec agitare consilia, cum neque excommunicandos, neque excommunicatores idoneos haberemus. Etenim vix trigesima populi pars doctrinam intelligebat, \& approbabat." Translation from Erastus, Theses of Erastus Touching Excommunication, trans. Robert Lee (Edinburgh, 1844), 2. 
of the people, Erastus asserted that the pro-consistory party was more concerned with strengthening ecclesiastical power by gaining the authority to take these "allurements to piety" away. In his opinion, the ministers should emphasize preaching the gospel and the proper use of sacraments in the attempt to nourish the Reformed faith among the populace. Both Erastus and disciplinists perceived the need for further Reformation of the Palatine church. Erastus offered the carrot; the disciplinists the stick.

Erastus likewise maintained that the entire idea of excommunication had become obsolete since it was tied to the Roman Church's sacramentalism. Excommunication had been used to heighten the role of the sacrament, which in turn had resulted in an increase of the church's power. Through this development, "excommunication made men look for salvation in the sacrament." ${ }^{\prime 9}$ In the era of the Reformation, however, Protestants had rejected the sacramental system of medieval Catholicism. Erastus suggested that the natural corollary to this rejection was the repudiation of the practice of excommunication. Excommunication was an historical aberration, which Christians must now set aside like the many other "catholic errors." ${ }^{50}$ Erastus had conducted preliminary historical researches to determine the origin of the custom. He believed that the practice began around $200 \mathrm{AD}$. Erastus did not impugn any ill-intent on the Christians who initiated the practice, although he did contend that excommunication should have ended with the conversion of the Roman Empire. He argued that the practice lived on, since bishops in Late Antiquity were reluctant to yield this power which enabled them to control kings. Whereas many theologians approved of the famous example of Ambrose's excommunication of Theodosius, Erastus condemned the action of this great Latin father and asserted that in excommunicating the emperor, Ambrose had erred more gravely than Theodosius himself. ${ }^{51}$

The church discipline controversy forced Erastus to rethink his conception of the relationship between church and state. In doing so he returned to the Scriptures and particularly the Old Testament (O.T.). Erastus's contemplation of the relationship between priest and ruler

${ }^{49}$ Explicatio gravissimae quaestionis, 58 (thesis 72): "ut Sacramentis salutem homines adscribere coeperint."

50 Ibid., 56 (thesis 69): "errores catholicos."

${ }^{51}$ Ibid., 46-49, 57-58 (theses 59, 70). See also Walton, "Der Streit zwischen Thomas Erastus und Caspar Olevian," 239. 
among the ancient Israelites made a definitive impact on his concept of church-state relations. The examples of the Hebrew kings of the O.T. seemed normative to Erastus since these rulers were analogous to the godly princes he served in Reformation Germany. In the O.T. he found no examples of dual governmental competencies. Therefore, he argued that there should be only one government in a Christian nation and asserted that the state should possess the exclusive right to punish wrongdoers.

In his vision of the relations between church and state, Erastus followed the well-marked line of his Swiss predecessors. The Zurich tradition had made little effort to differentiate the spheres of church and state and, as Walton has commented, "the basic institution that Zwingli thought of when he spoke of the church congregation was the political assembly of the city." 52 Erastus, likewise, did not distinguish between religious and civil authority. For example, he suggested that in the New Testament "synagogue," which generally denoted a place of assembly, and "Sanhedrin," the Jewish council, both referred to the same thing: a Jewish assembly of magistrates. Thus, to be "cast out" of the synagogue as described in John 9:22 was to suffer a civil rather than a religious penalty. ${ }^{53}$ When he considered 1 Corinthians 5:5 and its admonition to "hand over this man to the devil," he likewise interpreted this "handing over" as turning the offending party over to the civil authorities. ${ }^{54} \mathrm{He}$ also argued that it transgressed the plain sense of the text to think that this "handing over to the devil" could have meant banishment from the sacrament. In this blurring of any possible distinction between a civil and a religious jurisdiction, all religious offenses became public offenses. ${ }^{55}$

This same association of the church body and the civil magistrate was made in Erastus's interpretation of the classic proof text for excommunication, Matthew 18:15-18. ${ }^{56}$ This passage states that unrepented sins

52 Walton, Zwingli's Theocracy, 129. Cf. Moeller, Imperial Cities and the Reformation, 46; Blickle Gemeindereformation, 98.

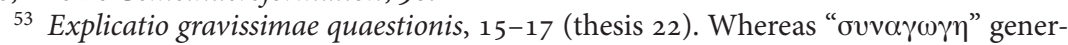

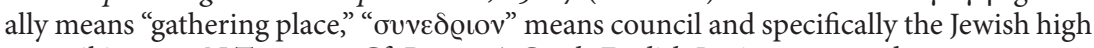
council in most N.T. usages. Cf. Bauer, A Greek-English Lexicon, 782 and 786.

${ }^{54}$ Explicatio gravissimae quaestionis, $46-49$ (thesis 59). " $\pi \alpha \varrho \alpha \delta\llcorner\delta \omega \mu . "$

${ }^{55}$ Cf. Heinz Schilling, "'History of Crime' or 'History of Sin?'-Some Reflections on the Social History of Early Modern Church Discipline," in Politics and Society in Reformation Europe, ed. E.I. Kouri and Tom Scott (London: MacMillan, 1987), 289-310.

${ }^{56}$ Oecolampadius, Bullinger, and Calvin had all used this passage to validate their arguments. For Oecolampadius, see Baker, "Church Discipline or Civil Punishment," 8; 
should be told "to the church." ${ }^{57}$ However, Erastus suggested that "to the church" actually meant "to the council." ${ }^{8}$ This "council" was the magistrate rather than a church council. Erastus followed Zwingli here, who found that the city council was more than competent to make decisions on behalf of the church, although Erastus's unwillingness to perceive any separation between church and state was perhaps even stronger than Zwingli's. ${ }^{59}$ Erastus allowed that Christians, if they were living in a nonChristian land (among "Turks or papists"), could set up an independent civil jurisdiction, like the Jewish Sanhedrin under the Romans. ${ }^{60}$ However, were the magistrate Christian, this aspect of Matthew 18 no longer applied. Erastus here interpreted Matthew 18 through the lens of 1 Corinthians 6, where Christians were enjoined to settle their grievances amongst themselves rather than taking them before the courts of the heathens. ${ }^{61}$ When proper Christian magistrates ruled, however, their

for Bullinger, see ibid., 13; for Calvin, see John T. McNeill, ed., John Calvin: Institutes of the Christian Religion, trans. Ford Lewis Battles (Philadelphia: Westminster, 1960), 4.22.2 \& 3 (p. 1231).

57 Explicatio gravissimae quaestionis, 26-29 (thesis 42). Whereas Zwingli considered the offenses discussed in Matthew 18 to be public, or sins against the whole church, Erastus considers them private grievances. Erastus took this from the line "if a brother sins against you." The key here is "against you," which is in the second person singular in the Greek "'عıऽ бoı." Ironically, modern textual criticism is undecided as to whether this "against you" is actually part of the Greek text. Erastus suggests this passage is talking about the personal obligation of the individual Christian to forgive, and does not create an ecclesiastical mandate to punish offenses. Zwingli, alternatively thought the "against you" referred to the church corporately. E.J. Furcha and H. Wayne Pipkin, trans., Huldrych Zwingli Writings, 2 vols. (Pittsburgh: Pickwick, 1984), 1:227.

${ }^{58}$ Explicatio gravissimae quaestionis, 40 (thesis 52 ): "Tell it to the Church means nothing less than to tell it to the magistrate of your own people ..." (Dic Ecclesiae, non

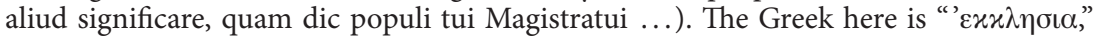
which connotes "the church or congregation as a totality of Christians living in one

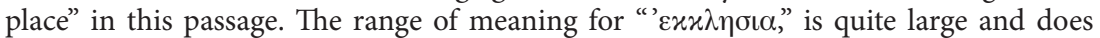
include the more general "assembly." (Bauer, A Greek-English Lexicon, 240-241.) This left Erastus room for interpretive play. Similar to his earlier conflation of " $\sigma v v \alpha \gamma \omega \gamma \eta$ " with

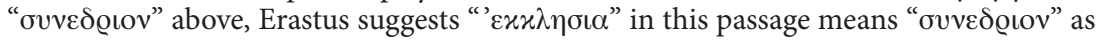
well. Explicatio gravissimae quaestionis, thesis 48.

59 G.R. Potter, "Church and State, 1528: A Letter from Zwingli to Ambrosius Blarer (4 May 1528)," Occasional Papers of the American Society for Reformation Research (1977), 115. Zwingli states of the council: "if it reaches a conclusion, is there any reason why you should want a separate agreement from the church?" In this particular circumstance, Zwingli is more saying that the town magistrates are competent to decide for the church, rather than that the town council is itself the church.

${ }^{60}$ Explicatio gravissimae quaestionis, 62 (thesis 75 ).

${ }^{61}$ Ibid., 33-34 (thesis 47). 
authority should not be duplicated. He argued that the church with the civil authority at its side had no need for excommunication: "We can now have no need to appoint for ourselves other judges and arbiters, besides the lawfully constituted magistracy." 22

From Erastus's use of the concept of the Jewish Sanhedrin, it should be clear that biblical examples were crucial for Erastus. Erastus followed the Zurich tradition of interpreting New Testament practices through Old Testament analogies. Erastus offered the Passover celebration of the Jews as a guiding paradigm for present day Eucharistic practice. ${ }^{63}$ Just as the Law of Moses did not prohibit anyone from partaking in the Passover because of sin, New Testament writers did not prohibit anyone from partaking in the Lord's Supper, since they could not void the Law. ${ }^{64}$ The example of Christ confirmed Erastus's opinion, since Jesus ate the Last Supper with Judas, a manifest sinner, confirming Mosaic practice of an open Passover. ${ }^{65}$ From these biblical examples Erastus concluded that "no baptized person is to be debarred from the Lord's table." 66

Ultimately Erastus simply desired to avoid clerical whim in the control of the Eucharist. He knew from experience that earnest believers often suffered from church strife. His theses narrated the past tyranny of the Roman Church, and Erastus wanted no part in Olevianus's party's effort to reassert an analogous tyranny. Erastus displayed his implicit anticlericalism with the rhetorical question: "Can we hope for better terms, or greater moderation, from our modern men, than the world has experienced in their predecessors?"67

After receiving Beza's response, Erastus fortified his position with a voluminous Confirmatio Thesium which, at 280 pages, made up the bulk

${ }^{62}$ Ibid., 40-41 (thesis 52): "quemadmodum neque iudices \& arbitros nunc necesse habemus nobis creare praeter legitimos magistratus."

${ }^{63}$ Ibid., $17-18$ (thesis 25 ).

${ }^{64}$ Ibid., 18, 26-29 (theses 26, 42).

${ }^{65}$ Although the synoptic gospels appear to imply that Judas was present with Christ at the Last Supper (as Erastus likewise surmised), some patristic writers disputed this interpretation. The majority of patristic interpretation, according to Kenneth Hein, argued that Judas did in fact take part in the Last Supper, though he did so "unworthily." K. Hein, Eucharist and Excommunication (Bern: Herbert Lang, 1973) 38-50. Not surprisingly, Bullinger also advocated this position, as early as 1531. Heinrich Bullinger Werke, 2. Abteilung Briefwechsel, 1:213.

${ }^{66}$ Explicatio gravissimae quaestionis, 20 (thesis 30).

${ }^{67}$ Ibid., 60 (thesis 72): "An speramus nostrae aetatis homines meliores aut continentiores esse antiquis?" 
of the printed Explicatio Gravissimae Quaestionis. The text lacked the vigor of the condensed theses but possessed all of its acerbity. Here is a listing of the book and chapter subdivisions with the chapter headings of the Confirmatio:

1. Preface (p. 67)

1.1 The definition of excommunication (p.67)

1.2 On the degrees or parts of excommunication (p. 91)

1.3 Defense of the arguments against excommunication which are drawn from the Old Testament (p. 103)

1.4 Defense of the arguments which have been accepted from the New Testament (p. 111)

1.5 Confutation of the arguments of Beza which offer support for excommunication from the Old Testament (p. 126)

2.1 On [ritual] impurity of law and morals (p. 130)

2.2 Confutation of the arguments which have been made for excommunication from the new covenant (p. 152)

3.1 On the office and distinction of the magistrate (p. 159)

3.2 On the power of the Sanhedrin in the time of the Romans (p. 176)

3.3 Refutation of Beza's interpretation of the words of Christ: "Tell it to the Church." (p. 186)

3.4 Defense of the true interpretation of passage 1 Corinthians 5 (p. 211)

3.5 Confutation of the arguments for excommunication assembled from the passage of Paul in 1 Corinthians 5 (p. 232)

3.6 Concerning yeast (fermentum) [i.e., 1 Corinthians 5:6-8] (p. 240)

3.7 Defense of our understanding of yeast (p. 242)

3.8 Refutation of the arguments for excommunication out of private conviction and those drawn from 2 Thessalonians 3 (p. 247).

3.9 Refutation of certain other arguments for excommunication (p. 254)

4.1 On the presbytery (p. 258)

4.2 Defense of the arguments against the presbytery of excommunicators (p. 259)

4.3 Confutation of the arguments by which some suppose to establish their presbytery (p. 266)

4.4 Whether the Sanhedrin was a political magistracy (p. 275)

4.5 Confutation of the arguments on behalf of the presbytery cobbled together from the New Testament (p. 283)

4.6 Concerning the election of presbyters, from whose judgment they should be based, and when they were instituted (p. 285)

4.7 Whether the power of excommunication was in the hands of the presbytery (p. 294) 
5.1 On the use of excommunication (p. 298)

5.2 Confutation of other various arguments which have been contrived by others for excommunication (p. 303)

6.1 Confutation of two short Latin treatises in favor of excommunication [contra Zanchi \& likely Boquin] (p. 317)

6.2 Refutation of another treatise in favor of excommunication [contra Ursinus] (p. 331)

In the first lines of the preface, Erastus affirmed that excommunication or debarring people from the sacraments remained the topic in question; furthermore the present debate only considered individuals who possessed an understanding of the Christian faith, acknowledged their sinfulness, and nevertheless desired to take part in communion. ${ }^{68}$ The first five books of the Confirmatio represented Erastus's reply to Beza, while the final book represented Erastus's replies to his Heidelberg colleagues. ${ }^{69}$ Erastus's tone was markedly friendlier in his response to Ursinus compared to his rejoinder to Beza. At the end of the Confirmatio, Erastus's editor appended many letters from Zurich in support of Erastus.

Of particular interest in the Confirmatio is the first chapter of the third book entitled "On the Office and Distinction of the Magistrate." Here Erastus repeatedly asserted the unitary nature of political authority, based on both rational and biblical arguments, with lines such as:

Since God, they say, hated all disorder, and wanted all things to be ordered in decency and propriety, he would have considered two heads in one body to be a monstrosity. Hence, in the Christian community he does not want there to be two distinct magistrates of equal power ruling the entire community. ... In summation, in a Christian state there is one magistrate, to whom is committed by God the external government of all things which belong either to civil life or to the life of Christian piety; that the right and authority of rule and jurisdiction has not been conceded to ministers or to any others. ${ }^{70}$

${ }^{68}$ Confirmatio Thesium, in Explicatio Gravissimae Quaestionis, 67.

${ }^{69}$ Bonnard, Thomas Eraste, 83-85.

70 Confirmatio Thesium, in Explicatio Gravissimae Quaestionis, 161-162: "Deus, aiunt, cum oderit omnem ' $\alpha \tau \alpha \xi\llcorner\alpha v$, \& omnia velit ordine decenti \& ' $\varepsilon v \sigma \chi \eta \mu o v \omega \varsigma$ fieri, duo in uno corpore capita ponere monstrosum putavit. Hinc in civitate Christiana non voluit duos esse magistratus distinctos aequali potestate totam civitatem regentes.... Summa est, Magistratum in Christiana Repub[lica] unicum esse, cui a Deo commissa sit gubernatio externa rerum omnium, quae vel ad civilem, vel ad piam \& Christianam vitam pertinent: ius et autoritatem imperandi ac ius dicendi neque ministris neque aliis ullis concessum esse." 
While the argument is rational and biblical, it relied more on the precedent of the Israelite state of the Old Testament than on the example of the nascent Christian community of the New Testament. Erastus argued, "Not a word may be produced from all of the books of the Old Testament which sanctions such a dual imperium, political and ecclesiastical." ${ }^{\text {11 }}$ After this blanket repudiation of dual authority he offered a proof of his claim with a summary history of the Israelite state from Moses to the Hasmoneans. This chapter is followed by a review of the power of the Sanhedrin in the Roman period. Erastus asserted that the Sanhedrin originally exercised jurisdiction over both sacred and political affairs. However, around the time of Christ most of the political authority passed into the hands of the Romans, leaving the Sanhedrin with ruling authority only over religious affairs. Nevertheless, it retained the power of the sword, that is, the right to inflict corporal punishments on malefactors, which is more associated with political authority, even as the Romans usurped some of the Sanhedrin's political competence. In Erastus's view, even if its jurisdiction had contracted, the Sanhedrin remained in essence a legitimate political magistracy. ${ }^{72}$

Despite his continued trumpeting of the superiority and indivisibility of political authority, Erastus remained rather anti-Erastian, in popular parlance, in his willingness to allow any political authority to establish religious policy. He struck something of a non-Erastian tone when he asserted: "In another [state], if perhaps the magistrate holds a false creed, the division of jurisdictions may in some sense appear tolerable."73

Not unlike the original theses, Erastus's views in the Confirmatio were chiefly based on his reading of Scripture, on this occasion fortified by a study of Josephus and the church fathers in addition to a more limited

71 Ibid., 163: "Constat primum, nullum posse in omnibus libris testamenti veteris verbum ostendi, quo duplex istud imperium, Politicum \& Ecclesiasticum approbetur."

72 Ibid., 179-180: "Dixi Gabinii tempore, antequam Romani suos praesides Hierosolymis haberent, Synedrium habuisse potestatem de politicis \& sacris rebus pariter iudicandi. At tempore Pilati aliorumque talium Praesidum, pars maxima huius potentiae ad Romanos transiit: ac relicta ipsi est de solis rebus ad religionem attinentibus iudicandi facultas. Haec autem non erat iurisdictio ecclesiastica, ut vos hodie à Politica discernitis: sed Politicae, quam prius totam possederat, pars erat. Nam ius gladii, carceris, plagarum, retinebant, quae vos ad ecclesiasticam potentiam pertinere negatis. Summa est, Magistratus erat legitimus \& politicus quamvis non de omnibus causis, ut prius, sed de certis solum cognosceret."

73 Ibid., 162: "In alia, in qua videlicet Magistratus falsam tuetur sententiam, certo quodam modo tolerabilis videri fortasse possit divisio rectionum." 
knowledge of scholastic authorities. He does not reveal explicit dependence on many prior theologians or political theorists. He was aware of the earlier controversy within the French Reformed tradition associated with Jean Morély, who denied the presbytery power over excommunication, and noted with irony that Morély had been excommunicated by the Genevan Church for his views. ${ }^{74}$ Erastus also cited the support of Peter Martyr Vermigli for his general conception of the unitary nature of political authority, but he conceded that Vermigli's view of the role of elders was quite different than his own. With the exception of the odd mention of Thomas Blarer of Constance and the Wurttemberg theologians' rejection of the dual order of presbyters, the work is relatively thin on references to sixteenth-century events or works. ${ }^{75}$

The main contention of Erastus's work was that prohibiting Christians from taking part in the sacraments had no biblical justification. This discovery had a decisive impact on his understanding of church discipline in general and church-state relations in particular. It is important, however, not to lose sight of Erastus's central concern: excommunication itself was the primary topic of his theses and their defense. Inherently related to excommunication was the institutional structure of church discipline. Likewise, any question of who should properly exercise discipline in a Christian commonwealth begged the question of the relationship between church and state. The development of Erastus's thought in the Explicatio gravissimae quaestionis can be compared to throwing a rock in a pond. The initial splash made by the rock was Erastus's decisive rejection of excommunication. The first surge caused by the splash was his reinterpretation of church discipline-though in line with the conventional Zurich model. The final wave created by the splash was his interpretation of church-state relations. In the conventional understanding of Erastianism, his ideas of church-state relations, viz., his denial of the validity of an independent ecclesiastical jurisdiction in a Christian state and the concomitant empowerment of the magistrate over the church, have been taken to epitomize his thought. Seen from within the context of the controversy, these "Erastian" ideas were not his central argument, but were the posture that he was driven to take in his attempt to refute the Gnesio-Calvinists' assertion that church discipline was mandated by divine law and was a mark of the true church. As Johann Heckel com-

\footnotetext{
74 Ibid., 69-70.

75 Ibid., 172-173, 291.
} 
mented, "on the search for support for his view, he found a truly epochmaking juristic distinction." 76 Even here, however, Erastus was not essentially more radical than his Swiss predecessor Wolfgang Musculus. Erastus drew from him the dictum that "nature denies two authentic governments in the same people, whereof one is not to be subject to the other." ${ }^{\prime 7}$ The force of Erastus's theses was directed at undercutting the rationale for an independent consistory to police morals; not recognizing the autonomous jurisdiction of the church vis-à-vis the state was simply a means to further this argument. ${ }^{78}$

To what extent was Erastus original and why did he become the most famous or infamous representative of the general Swiss-German view of church-state relations? As has been commonly observed, the notion that there can only be one legitimate sphere of power within a Christian state was not new with Erastus and flowed from the thought of Zwingli, Bullinger, and Musculus. Erastus's thought also shared some similarity with that of Peter Martyr Vermigli, whom he acknowledged. ${ }^{79}$ Erastus was working within this tradition and the continuity of his thought with his forerunners' positions was more marked than his novelty. However, Erastus did frame his argument in a way which made both his Calvinist detractors and his later English partisans recognize that a line had been crossed and that Erastus's formulation represented a new type of challenge.

A key difference between Erastus and his predecessors was his polemical intensity. To a certain extent this polemical escalation flowed naturally from the genre of the works. Erastus, a master of the disputation, arranged his work in argumentative theses which sharpened the contrast between his views and those of his disciplinist colleagues. Whereas Bullinger's Decades and Musculus's Loci Communes offered rambling

${ }^{76}$ Johannes Heckel, "Cura religionis, Ius in Sacra, Ius circa Sacra," in Festschrift Ulrich Stutz zum siebzigsten Geburtstag [Kirchenrechtliche Abhandlungen 117-118] (Stuttgart: Ferdinand Enke, 1938), 292: "Auf der Suche nach Beweisen für seine Ansicht fand er nun eine wahrhaft epochemachende juristische Distinktion."

77 Explicatio gravissimae quaestionis, introduction, $\left[\mathrm{A} 5^{\mathrm{r}}\right]$ : "Natura negat, (inquit Musculus) in eodem populo duas authenticas gubernationes, quarum una non sit alteri subiecta." See Wesel-Roth, Thomas Erastus, 110-112.

${ }^{78}$ It is important to remember Erastus's context and that his theses assumed a Christian magistrate. On other occasions he seemed to suggest that the precise church-political matrix was an issue of adiaphora.

${ }^{79}$ See John Patrick Donnelly, Calvinism and Scholasticism in Vermigli's Doctrine of Man and Grace (Leiden: Brill, 1976), 188. 
textbook treatments which did not as a rule impose as strong a reading on the topics under consideration, Erastus's theses were intentionally posed in a confrontational manner. Erastus's presentation was a stake directed at the heart of the Calvinist disciplinary regime. Beza and Dathenus sensed this rhetorical and theological gap between Bullinger and Erastus and complained bitterly about Erastus's wholesale repudiation of their entire disciplinary system. ${ }^{80}$ Thus, it was not by accident that later English divines focused on Erastus as a source of inspiration, nor that seventeenth century Presbyterian critics identified him as a figure who could perhaps be attacked without repudiating the entire German-speaking Swiss Reformed heritage.

A second difference was Erastus's assault on the concept of excommunication in toto. Whereas it had been common among the Swiss to leave definitive excommunication in the hands of secular authorities and in a de facto sense make excommunication a dead issue, they still tended to more or less accept the concept of excommunication even if in a severely limited form. Since consistorial discipline with excommunication was cherished by their Genevan brethren, with whom they wanted to maintain cordial relations, the general tendency of their rhetoric was to regard the specific form of discipline as a matter of adiaphora. While the Zurich and Bernese church leaders might have worked assiduously to curb the expansion of Calvin's model outside of Geneva, which they did successfully in the case of the Vaud and attempted to do in Heidelberg, they still did not want to demonize their coreligionists. As we have seen, Erastus went far beyond this and boldly proclaimed that the entire concept of excommunication was without theological justification or biblical merit. This impolitic assertion seems to have limited Erastus's appeal in Heidelberg in the 1560 s, as men like Ursinus, who agreed that the conditions were not propitious for the erection of consistorial discipline, nevertheless could not stomach Erastus's sweeping repudiation of so much of the conventional wisdom.

Closely related to this point was Erastus's rejection of the claim that presbyterial authority was founded upon divine right. For Erastus, presbyterial authority was only an ad hoc arrangement for jurisdictions that were not blessed to live under a Christian sovereign. In making this argument, he elevated the vision of ancient Hebrews living under monarchy as the apposite model for how church-state relations should oper-

80 Discussed below. 
ate in a Christian society. This naturally relates to a further contribution of Erastus, which was his exposition of an alternative hermeneutical basis for the Zurich-Bern vision of church-state relations. Zwingli and Musculus had previously intimated that the kings of the ancient Israelites were appropriate models for contemporary Christian princes. Erastus buttressed this assertion with an investigation of the role of the Sanhedrin in Jewish life in the era both immediately prior to and after the time of Christ, based on a close reading of Josephus. Given that his seventeenth-century followers Thomas Coleman, John Selden, and John Lightfoot were formidable Hebrew scholars, Erastus's treatise and his reply to Beza offered these followers a powerful historical counterargument to wield against the de jure divino claims of the advocates of presbyterial discipline. ${ }^{81}$ While Erastus may have been inspired in part by one of the sixteenth century's greatest Hebraists in Pellikan and, in turn, inspired some of the seventeenth century's greatest Hebrew scholars to adopt a similar position, his own opinions were apparently based on Greek and Latin language sources rather than an intimate knowledge of Semitic texts.

Viewed from the perspective of the social history of ideas, Erastus's thought displayed a marked continuity with two powerful pre-Reformation tendencies. His vision of church-state relations largely reflected that of the cities and towns of pre-Reformation Switzerland and southwestern Germany. These communities had been usurping ecclesiastical jurisdictions before the Reformation and the acceptance of the Protestant gospel merely consolidated this process. ${ }^{82}$ Thus, while there may have been notions borrowed from such theorists as Marsilius of Padua in Erastus's thought, Erastus's Swiss civic heritage supplied the animating force to his theory. ${ }^{83}$ The novelty of Erastus is that, rather than delivering power over the church into the hands of a quasi-republican city council, the Heidelberg context pushed this transfer into the hands of the Christian prince. Since both types of government were dominated by a thin layer of individuals at the top of the social hierarchy, the difference between the Swiss canton and the German principality was not perhaps as large

${ }^{81}$ See Confirmatio thesium, in Explicatio gravissimae quaestionis, 176-186; 269-283. See Johann P. Sommerville, "Hobbes, Selden, Erastianism, and the History of the Jews," in Hobbes and History, ed. G.A.J. Rogers and Tom Sorell (London: Routledge, 2000) 168174 .

${ }^{82}$ See Moeller, Imperial Cities and the Reformation.

${ }^{83}$ On the influence of Marsilius on Bullinger and the Swiss, see Walton, "Der Streit zwischen Thomas Erastus und Caspar Olevian," 234. 
as one might conventionally imagine. Bullinger and Gwalther, along with Erastus, felt that this model of church discipline was equally applicable to a principality.

A concomitant force was also evident in the writings of Erastusanticlericalism. Recent research has established how pervasive anticlericalism was in southwestern Germany on the eve of the Reformation. ${ }^{84}$ For many of these Germans, one of the primary components of the "freedom of the Christian" was the liberation from clerical tyranny. This preReformation sentiment survived as a driving force in Erastus's thought. Related to this theme was Erastus's reprise of the early Protestant rhetorical strategy of contrasting the church's rules and traditions, "the laws of man," with the clear teaching of the Bible. Ironically here, Erastus made the Calvinist church leaders, rather than the Catholic authorities, the purveyors of corrupted and tyrannical tradition. The original impulse of Erastus's "Erastianism" was not to grant the Leviathan state dominion over the church, but to preserve Christian liberty from state-sanctioned clerical oppression.

\section{Strife in Heidelberg and Beyond}

In Erastus's estimation, a five-man cadre drove the movement to establish a church consistory on a Genevan model in Heidelberg: Zuleger, Olevianus, Dathenus, Ehem, and Konrad Marius. ${ }^{85}$ The only one of these men to have undertaken proper theological studies was Dathenus. The other four were more properly legal scholars by education, though both Zuleger and Olevianus had at least logged a few months at Calvin's feet in Geneva. With his leading position in the church, Olevianus headed the disciplinist party, leading some to dub the group "Olevianists." Even the usually mild Ursinus judged that Olevianus "reigned" over Zuleger, Ehem, and the elector himself. ${ }^{86}$ Although he served as the chief agitator for the independent consistory and obviously cared deeply about its implementation, Olevianus did not take up the pen himself to advocate the system or refute Erastus and Sylvan. The Bohemian Zuleger, who

\footnotetext{
${ }^{84}$ See Peter D. Dykema and Heiko A. Oberman, eds. Anticlericalism in Late Medieval and Early Modern Europe [SMRT 51] (Leiden: Brill, 1993).

${ }^{85}$ Erastus to Bullinger, Nov. 21, [1569], StAZ, E II 361, fol. 77.

86 "Causa est, quia Olevianus Zulegerum, hic Ehemium, hic Josiam [Frederick] regit." Ursinus to Crato, Nov. 9, 1575. Sudhoff, C. Olevianus und Z. Ursinus, 393, Press, Calvinismus und Territorialstaat, 250.
} 
became the president of the church council and grew into a formidable player at court, was with or ahead of Olevianus at every step. The two appear to have been the primary instigators behind the controversial iconoclasm campaign of 1564-1565. With Zuleger, Olevianus, and Marius all ensconced on the church council, it is clear where their chief strength lay. The cooperation of this trio had its origins in their days as law students in Bourges, where they participated in the underground Huguenot church. ${ }^{87}$ The jurist Ehem had by this point yielded his university position to serve at court. He was a fixture of Palatine politics for decades and even returned to Heidelberg as chancellor during the regency of Johann Casimir. Wesel-Roth offered something of a Machiavellian interpretation of Ehem's role in this process, and went so far as to suggest that the later "terror" policies of the church council, which stifled the internal dissent, were useful to Ehem as it gave him a free hand in external political affairs. ${ }^{88}$ The interventionist Palatine foreign policy on behalf of the Dutch and French Reformed communities and the Calvinist disciplinist urge were clearly related phenomena, but they did not necessarily follow each other in lock step. Marius was likewise a committed Calvinist who also happened to be Ehem's brother-in-law. ${ }^{89}$ Dathenus was a stirring preacher and tireless organizer who was credited with fomenting iconoclasm in the Netherlands and whose intemperate rhetoric would later provoke the wrath of William the Silent. ${ }^{90}$ As this conflict reached its high point, Dathenus took the lead in representing the cause of the Palatine disciplinists to foreign Reformed churches and may have briefly eclipsed Olevianus as the leader of the disciplinist faction. This was a tight, genuinely Calvinist group that was also passionately committed to assisting the struggle of their Reformed brethren in France and the Netherlands.

Though the theological faculty favored the Calvinist vision of church discipline over the Zurich system, it is important to note that the impetus for adopting a purer Calvinist system came more from within the upper echelon of the church itself rather than from the university. Nevertheless, the all-foreign theological faculty (one Frenchman, Boquin, and two Italians, Tremellius and Zanchi) played a significant role in promoting

\footnotetext{
87 Goeters, “Olevianus als Theologe," 290-291.

88 Wesel-Roth, Thomas Erastus, 65.

89 Press, Calvinismus und Territorialstaat, 243.

90 Phyllis Mack Crew, Calvinist Preaching and Iconoclasm in the Netherlands, 15441569 (Cambridge: Cambridge UP, 1978); Johan Decavele, "Petrus Dathenus," in OER, 1:464-465; C.V. Wedgwood, William the Silent (New York: Norton, 1968) 195-198.
} 
the disciplinists' aims. Both Boquin and Zanchi authored memoranda that favored the erection of consistorial discipline. ${ }^{91}$ Tremellius's views are more difficult to discern, though his closest associations were with the disciplinists. ${ }^{92}$ Along with writing on behalf of the Calvinist system, the foreigners' church in Heidelberg, where these theologians worshipped and ministered, served as the prototype for implementing the consistory model on the rest of the Palatinate. Indeed, these three served as the first elders in the foreigners' church consistory. ${ }^{93}$

As many contemporaries remarked, there was a split in support of the parties between the German and foreign populace in the Palatinate, with the foreigners (chiefly French and Netherlandish) lining up solidly in the disciplinist camp. ${ }^{94}$ Of all the foreign groups, the Dutch were the most numerous and influential in the Palatinate. Dutch refugees had streamed into the Palatinate since the early 1560 . They possessed a large community at Frankenthal that would prove one of the most important refugee gatherings outside of Emden. ${ }^{95}$ The Dutch presence was becoming so burdensome that Erastus quipped in a letter to Bullinger, "They should add to the litany: 'Save us from the Netherlanders, O Lord." "96 The sense of excessive Dutch influence became extreme in April of 1569 when Elector Frederick married the Baroness Amalie von Neuenahr zu Limburg, the widow of Hendrik van Brederode, one of the leaders of the Dutch revolt. Erastus heaped scorn on the marriage in a contemporary letter to Bullinger and thought it revealed the mani-

\footnotetext{
${ }^{91}$ Boquin's memorandum has not been identified among his printed works. "H. Zanchius ad Illustrissimum Principem Fridericum III. De Excommunicatione," Operum theologicorum ([Geneva?]: Stephanus Gamonetus, 1605), 7(2):139-147. Zanchi's position can also be observed in his letter to Johannes Wolf in Hieronymi Zanchii Bergomatis, Theologi Clarissimi, Epistolarum Libri Duo ... (Hanau: Antonius, 1609), 63-64. Burchill has argued that Zanchi, like Ursinus, "sought to maintain the middle ground." Burchill, "Girolamo Zanchi: Portrait of a Reformed Theologian and His Work" SCJ 15 (1984): 201.

${ }^{92}$ One circumstantial piece of evidence for Tremellius's likely pro-disciplinist position is that Pigafetta waited until he had become rector to launch his accusations against Erastus. See below.

${ }^{93}$ Erastus to Bullinger, July 8, (15)69, StAZ, E II 346a, fol. 551 "v: "Ecclesiam instituerunt Gallicam, qualis olim Argentinae erat: in qua iam Seniores instituti sunt, Boquinus, Tremelius, Zanchus." Benrath, "Die Korrespondenz zwischen Bullinger und Thomas Erastus," 119.

${ }^{94}$ Horn, "Johann Sylvan," 251-257; Wesel-Roth, Thomas Erastus, 60. Alternatively, Horn notes that the Polish students tended to favor Erastus.

${ }_{95}$ Schaab, Geschichte der Kurpfalz, 2:101.

${ }^{96}$ Erastus to Bullinger, Feb. 2, 1569, Zurich, Staatsarchiv des Kantons Zürich, MS E II 346a, fols. 549-550: "Man solt in die Letanei gesetzt haben/ à Niderlandris, libera nos Domino, sagt iener."
} 
fest hypocrisy of the disciplinists for matching the pious elector with this young, luxury-loving widow. ${ }^{97}$ This scandalous marriage, tying one of the highest ranking princes to someone below his station, was a clear revelation of the strength of the Dutch-disciplinist party in Heidelberg.

There were a number of significant individuals who adopted a moderate stance on the church discipline question or whose positions have not been investigated in depth. For example, one would not have expected that the noted Philippist Lutheran theologian Victorinus Strigel, who had only joined the university and church council in 1567 , would have been naturally inclined to support the Geneva program. His death in June of 1569 robbed the anti-disciplinists of a potential ally.

It is likewise difficult to categorize Ursinus's position as a straightforward endorsement of the disciplinist cause. The controversy itself unnerved Ursinus, and he attempted to remain above the partisan fray. As a true student and spiritual heir of Melanchthon, Ursinus has been the subject of much debate regarding whether he should ultimately be labeled a "Lutheran" or a "Calvinist." Often assessed merely between the poles of Wittenberg and Geneva, he remained in much closer contact with Bullinger and company than with Calvin and Beza. ${ }^{98}$ Though history has rightly recognized Ursinus as the most perspicacious theologian of the Heidelberg Reformed, he never possessed the personal influence there that Calvin exercised in Geneva, or Melanchthon exercised in Wittenberg-a fact he himself bemoaned ${ }^{99} \mathrm{He}$ had given up his position on the university faculty to dedicate all his labors to training pastors at the Collegium Sapientiae. He was not a member of the church council and never played a large role in church politics. ${ }^{100}$ Ursinus was a retiring personality whose small tolerance for controversy had already been exhausted. After the Maulbronn colloquy, he was extremely reluctant to step into theological conflict as he demonstrated at Amberg to the

97 Erastus to Bullinger, March 6, 1569, StAZ, E II 361, fols. 14-14av. Press, Calvinismus und Territorialstaat, 253 and Benrath, "Die Korrespondenz zwischen Bullinger und Thomas Erastus," 116-117. The "Bildnis des Kurfürsten Friedrich III. des Frommen von der Pfalz und seiner beiden Gemahlinnen Maria von Brandenburg-Kulmbach und Amalia von Neuenahr" can be seen at the Haus der Bayrischen Geschichte (http://www .hdbg.de/).

98 Benrath, "Briefe des Heidelberger Theologen Zacharias Ursinus," 96-97.

99 Benrath, "Briefe des Heidelberger Theologen Zacharias Ursinus," 98. Cf. Peter Lillback, "Ursinus's Development of the Covenant of Creation: A Debt to Melanchthon or Calvin?” Westminster Theological Journal 43 (1981): 247-288.

100 Burchill, "On the Consolation of a Christian Scholar," 573. 
disappointment of Frederick. In the controversy over church discipline, one has the sense that his personal sympathies were on the side of the anti-disciplinists, but that he could not endorse the extremes of Erastus's position. The discord that the protracted controversy had sown in the young church both depressed and enraged Ursinus. Erastus considered Ursinus a close friend, as he revealed in a later letter of recommendation to Abraham Musculus in Bern. Erastus proclaimed of Ursinus, "no one who lives under the sun is dearer to me," but he also stated, "he has his peculiar customs, which are not approved of by all." 101 Regarding Ursinus's "peculiar customs," Erastus was perhaps referring to his melancholy cast, his perpetual complaining, and his tendency to withdraw from worldly affairs. At any rate, Erastus was no doubt disappointed that he did not receive Ursinus's full support, and relations between the two men apparently grew tense during the controversy. ${ }^{102}$

In fact, Ursinus opposed both factions in the conflict over church discipline. He was angry that the disciplinist church leaders were pushing their vision of an enhanced disciplinary regime at an inopportune occasion. Yet he was angrier still with their espousal of an interventionist foreign policy on behalf of the French and Dutch Protestants. On the very eve of Withers's doctoral defense, Ursinus sent a memorandum to the elector both lamenting the fact that the church was provided with "inept pastors" and that the church council was "torn, discordant, dreaming of an untimely discipline." He further decried their neglect of their primary vocation and declared that they were "more concerned with war than with peace." 103 A year later Ursinus was still despondent about the state of the Palatine church. Ursinus not only poured his scorn upon the "new schemes" of the disciplinists, but he also faulted Erastus himself and his group of partisans in a letter to Johannes Crato von Krafftheim. "Erastus is the head of the faction against ecclesiastical censor: his followers are

${ }^{101}$ Erastus to A. Musculus, Nov. 23, (15)77. Autograph, Zofingen, no. 1.53: "Putavi, neminem sub sole vivere, qui amicior mihi esset." "Sed suos habet mores peculiares, qui non omnibus probantur."

${ }^{102}$ In his preface to the Explicatio gravissimae quaestionis, Erastus mentions giving his theses to be judged by an individual "I esteemed to be as dear a friend to me as was living" (quo mihi amiciorem vivere neminem putabam), $\left[\mathrm{A} 6^{\mathrm{v}}\right]$. This comment would seem to refer to Ursinus, especially in view of Erastus's comment to Abraham Musculus quoted above.

103 "Monita D.D. Ursini Friderico III. Electori proposita per Steph. Cirlerum camerae secretarium 1568 26. Maii," in Kluckhohn, Briefe Friedrich des Frommen, 2(2):1053-1055. "Senatum ecclesiasticum esse lacerum, discordem, immaturam disciplinam somniantem, quique hoc tempore magis bello quam pace sit occupatus" (p. 1054). See Press, Calvinismus und Territorialstaat, 264; Visser, Zacharias Ursinus, 147-170. 
Xylander, Sylvan, [Johann] Willing - this one indeed an unlearned and arrogant demagogue; they infect many in the school and among the ministers." 104 Such a comment to their mutual friend Crato supplies the background to understand Erastus's contemporaneous exclamation: "Ursinus rages, although he does not differ much from us. Were he not insane, he would be able to agree with us." 105

On the question of church discipline, however, Ursinus did not agree with Bullinger and Erastus, or with Olevianus for that matter. At the request of the elector, Ursinus wrote a brief "Judgment on Ecclesiastical Discipline and Excommunication" that most commentators have assessed as having come down between the two camps. ${ }^{106}$ Though he rejected Erastus's outright repudiation of the power of the keys and dismissed many of the proof texts with which Erastus supported his position, he clearly did not see church discipline as the panacea that his Calvinist colleagues did. Unlike Erastus and the Zurich theologians, he did think that the church had a role to play in discipline, which could be exercised along the consistory model. He did not think that this body should be independent of state control, however, and also thought that excommunication itself should be extremely rare. In short, Ursinus considered church discipline to be quite biblical in theory but that its implementation should be restricted only to the most exceptional cases. While Erastus obviously recognized their disagreement, he both respected Ursinus's response and felt that the gap between them was less than that

${ }_{104}$ Zacharias Ursinus to Crato, Nov. 3, 1569. Quoted in J.F.A. Gillet, Crato von Crafftheim und seine Freunde: Ein Beitrag zur Kirchengeschichte, 2 vols. (Frankfurt/M., 18601861), 2:498-500 (no. 34) and Bonnard, Thomas Éraste, 80 (with the key section translated from Greek into Latin): "Erastus caput factionis est contra censuram ecclesias-

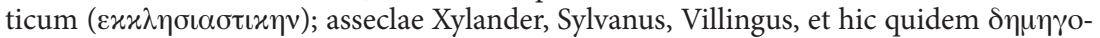
@os indoctus et superbus."

105 Erastus to Bullinger, Nov. 21, [1569], StAZ, E II 361, fol. 77: "Ursinus furit, quamquam à nobis param absit. Nisi insaniret, posset nobis convenire." Discussed in Visser, Zacharias Ursinus, 152. Erastus also made an off-hand comment in a letter to Volcher Coiter revealing some strain with Ursinus: "Causam irae Ursinus nullam habuit," Aug. 28, n.y. [ca. 1570-1575], Basel, Öffentliche Bibliothek der Universität Basel, MS G2 II 37, fol. 11. This remark suggests that Ursinus's displeasure with Erastus had been widely communicated amongst the larger Crato-Ursinus circle.

106 Zacharias Ursinus, "Judicium de Disciplina Ecclesiastica et Excommunicatione: Ad Electorem Fridericum III. Pium, Anno 1569," in Opera Theologica, 3:801-812. WeselRoth, Thomas Erastus, 59; Visser, Zacharias Ursinus, 151-154; Burchill, "On the Consolation of a Christian Scholar," 573-574. Ursinus's position can also be observed from his catechetical lectures which in no way agreed with Erastus's position. The Commentary of Dr. Zacharias Ursinus on the Heidelberg Catechism, 440-463. 
of others who had opposed him. ${ }^{107}$ He was also encouraged that Ursinus did not want to give the consistory jurisdiction over excommunication with no governmental oversight. Derk Visser has emphasized that though Ursinus did take up a position against Erastus, he was soon reconciled to him, and unlike Olevianus and his partisans, he never broke off communication with Bullinger. ${ }^{108}$ Many years later Erastus reported to Gwalther that Ursinus's opinion on church discipline had moved further from the Gnesio-Calvinists, but that he feared making this public. ${ }^{109}$

While the anti-disciplinists were clearly isolated within the church hierarchy, they were well represented at court and within the university. ${ }^{110}$ With good reason, past accounts have viewed Erastus as the linchpin of the anti-disciplinist faction. With his position at the university and his relationships within the church and at court based on his former position on the church council, he was a natural focal point for the opposition. Though most of the top clerics and university theologians were in the disciplinist camp, the opposition also had support within the church, if in general from somewhat disaffected pastors.

The most highly placed cleric on the side of the anti-disciplinists was the court preacher Johannes Willing. He played his most prominent role in Palatine politics in the period preceding the Augsburg diet of 1566, and he remained on especially good terms with Count Palatine Johann Casimir. Though Erastus expressed confidence in his ability and his character, most historians have suggested that personal ambition drove his passion for the anti-disciplinist cause. After the fact, Sylvan alleged that Willing had egged on the entire opposition movement in an attempt to replace Olevianus as head of the church. ${ }^{111}$ Eventually, Willing

107 Erastus to Grynaeus, Jan. 24, [1570], Basel UB, G II 4, fol. 278: "Scripsi nuper, me respondisse Bezae, et tribus aliis, Boquino, Zancho, Ursino. Hic à nobis minimum dissentit in rei substantia."

108 Benrath, "Briefe des Heidelberger Theologen Zacharias Ursinus," 97; Visser, Zacharias Ursinus, 154.

${ }^{109}$ In the context of composing a new confession, Erastus asks Gwalther: "Vellem te ipsi scribere, ut in Confessione scribenda non misceat negocium Excommunicationis, quae fit exclusione à sacramentis, ne novae oriantur turbae. Scio eum rem intelligere. Sed quia semel contradixit ferociter, non vellet videre erravisse." Erastus to Gwalther, Nov. 15, 1577, Zurich, Zentralbibliothek, MS A 49, 310-311.

110 See Appendix A for faculty roster as of Dec. 22, 1568.

111 Sylvan to Erastus, Heidelberg, [October] 1570, Heidelberg, Universitätsarchiv Heidelberg, MS A-160/ 10, fol. 179. Printed in Hans Rott, ed. "Neue Quellen für eine Aktenrevision des Processes gegen Sylvan und seine Genossen," Neues Archiv für die Geschichte der Stadt Heidelberg und der rheinischen Pfalz 8 \& 9 (1910 \& 1911): 14-16: "Clarum est, 
would lose his high standing in the church through his intrigue with the anti-disciplinists. He does not appear to have been involved in the Antitrinitarian affair and died of natural causes before the resolution of Sylvan's case. ${ }^{112}$

Johann Sylvan stood out as the most theologically astute cleric among the anti-disciplinists. ${ }^{113}$ Little is known about Sylvan's early life other than the fact that he seems to have been born in the South Tyrol, in modern Italy. After studies at the University of Vienna where he took a licentiate in theology, Sylvan took employment as a court preacher in the service of the bishop of Würzburg. Thus Sylvan was born, educated and spent much of his early professional life within the old church. This commitment, however, would not endure. Sylvan was an open and reflective person for whom the quest for theological certainty must have seemed something like peeling off the layers of an onion in a perpetual quest for purer truth. Such intellectually malleable individuals like Sylvan found themselves conversion prone in this highly charged confessional era, and he in fact would travel a path from Catholicism to Lutheranism to the Reformed faith and, ultimately, Antitrinitarianism. He desperately wanted to reverse the final step, but his judges would not oblige.

While in the employ of the bishop of Würzburg, Sylvan came under the influence of Lutheran preaching at the diet of Regensburg. His conversion to Lutheranism followed after he had been charged with the task of defending the Catholic view of justification. He left the Catholic diocese of Würzburg and found refuge in Lutheran Württemberg. The Swabians were originally uncertain whether his conversion was genuine, but a printed confession of faith served to vouch for his sincerity. ${ }^{114} \mathrm{He}$ did not tarry long in the Lutheran camp, though. One of his first Protestant works was an attack on images, the underlying assumptions of which

et Willingum mera ambitione eo venisse quo ampliorem haberet materiam exagitandi senatum ecclesiasticum." Summarized in Burchill, The Heidelberg Antitrinitarians, 99.

112 Willing was relieved of his duties on the church council and resigned his position as court preacher in the spring of 1569 . He first took a position at the Peterskirche in Heidelberg, where he replaced another anti-disciplinist Adam Neuser. He was then transferred to Bretten and later became Johann Casimir's court preacher in Kaiserlautern until he was released from this position in the spring of 1572 . He died on July 10, 1572. Benrath, "Die Korrespondenz zwischen Bullinger und Thomas Erastus," 118, 137-140. See Seeling, Johannes Willing (1525-1572).

113 Regarding Sylvan's life, see Horn, "Johann Sylvan," 219-310; Burchill, The Heidelberg Antitrinitarians, 21-27; Karlheinz Blaschke, "Johannes Sylvanus," OER, 4:132.

114 Brenz originally deemed his Bekenntnis "too harsh," and it had to be modified to please the Württembergers. Burchill, The Heidelberg Antitrinitarians, 29. 
appeared to share more with Reformed thought than Lutheranism, and soon he found that he disagreed with the Lutheran interpretation of the Lord's Supper and particularly the doctrine of ubiquity. Fortunately for Sylvan, his doctrinal difficulties coincided with the Palatinate's turn to the Reformed faith, and pastors of his caliber had little difficulty finding employment in Frederick's church. He seems to have been placed in Kaiserslautern in early 1563 , where he had something of a stormy relationship with his parishioners. They did not take kindly to his unilaterally renaming their children at the baptismal font to prevent giving the child a saint's name-proving that the disciplinists had not quite cornered the market on excessive zeal. Matthaeas Vehe-Glirius, the future Antitrinitarian and source of an entertaining account of the trip to Speyer that would prove their undoing, served as his deacon in Kaiserslautern. Since Sylvan's presence was increasingly required for theological and diplomatic tasks from the center of Heidelberg, he was transferred to Heidelberg, then more suitably assigned the post of superintendent at nearby Ladenburg. Christopher Burchill has compared his position to that of Ursinus, who like Sylvan was requested by the elector to compose a written opinion on the issue of church discipline. ${ }^{115}$

Another leader of the anti-disciplinist movement was the Heidelberg cleric Adam Neuser. We have already discussed his activities with reference to his possible participation in the authorship of the Heidelberg Catechism. Neuser's origins are even less certain than Sylvan's, though it is known that he was from Brandenburg-Ansbach, and it has been suggested that he studied with Wolfgang Musculus in Bern. ${ }^{116}$ Neuser was on good terms with the Swiss in general, and the Bernese in particular, as many students from Bern lodged in his home in Heidelberg. Though he did not possess an illustrious academic pedigree, contemporaries judged him an able theologian. In fact, the university senate had favored appointing him to the third chair of theology over Olevianus, though the elector overruled them. ${ }^{117}$ Later a rivalry with Olevianus would become evident, though it would be premature to suggest that it festered from 1561 onward. A theologian of some talent, Neuser purportedly defended the anti-disciplinist position at Withers's doctoral

115 Horn, "Johann Sylvan," 240; Burchill, The Heidelberg Antitrinitarians, 32, 86. He also refused to baptize one child since the chosen godfather "sei ein turck, ein Judt." Sylvan's views can be fairly clearly perceived in his letter to Johannes Wolf, Sept. 1, 1568, published in Horn, 297-300; Synopsis in Burchill, The Heidelberg Antitrinitarians, 77-78.

116 Burchill, The Heidelberg Antitrinitarians, 107-111.

117 Ibid., 113. 
disputation. His opposition to the plans of the church council likely was the root cause of his demotion from his position at the Peterskirche. His new job, serving under Olevianus at the Heiliggeistkirche, no doubt only added to his growing sense of alienation. It was also alleged that Neuser was overly fond of alcohol, a claim that critical historians accept. Even more so than in the case of Sylvan, Neuser must have realized by this point that his career in Heidelberg had run its course, and he was looking to relocate long before his Antitrinitarian beliefs were exposed. ${ }^{118}$

The anti-disciplinists' real strength did not lie in the church but at court and in the university. While the theological faculty was more or less behind the disciplinists, the anti-disciplinists predominated on the arts and medical faculties. ${ }^{119}$ In addition to Erastus, the medical professor Sigismund Melanchthon (1537-1573) actively resisted the disciplinary regime, even refusing to take a seat on the consistory when it was eventually put in place in 1573 . On the arts faculty, Wilhelm Xylander and Simon Grynaeus were solidly in Erastus's camp, while the other faculty members do not seem to have played an active role in the controversy. ${ }^{120}$ Xylander's facility as perhaps the premier scholar of classical Greek in the empire was an obvious asset. ${ }^{121}$ The instructor at the preparatory arts Paedagogium, Christoph Schilling, who later became caught in a turf war between the church council and the university, and the Dionysianum praeceptor, Timotheus Mader, were both associates of Erastus, which likely explains the level of hostility they later incurred from the disciplinist regime. ${ }^{122}$ The university provided a safe haven for Erastus and later proved its loyalty by electing him rector of the university in the midst of the Antitrinitarian affair.

Erastus possessed a long list of allies at court. Though they were a clear majority on the high council, the most influential of all the councilors,

118 Ibid., 107-108. Neuser's facility in the local dialect may have also enhanced his popular appeal. Alting, Historia de ecclesiis Palatinis, 102-103 (ch. 60).

${ }_{119}$ Unlike the later conflict in England, in the Heidelberg controversy the jurists did not play a leading role.

${ }_{120}$ Regarding Xylander, see Fr. Schöll in $A D B, 44: 582-598$.

121 After Xylander's death Erastus discussed his desire to have his annotated translation of the New Testament published. Apparently Xylander's interpretation of the key N.T. proof texts for church discipline (especially Matt. 18) was very favorable to Erastus's position. I have not been able to discover whether Xylander's translation was ever published. Erastus to Grynaeus, Sept. 14, (15)77, Basel UB, G II 4, fol. 209.

${ }^{122}$ Wesel-Roth, Thomas Erastus, 74; Burchill, "Die Universität zu Heidelberg," 243. For Mader, see Dagmar Drüll, ed., Heidelberger Gelehrtenlexikon 1386-1651 (Berlin: Springer, 2002), 364-365. 
Ehem, was not on their side. According to Volker Press, the chief steward Pleikard Landschad, the marshal Christoph von Gottfart, the justice of the peace Hartmann Hartmani, and the chancellor Christoph Prob all opposed the Calvinist disciplinary effort. Likewise, Frederick's secretary Stephan Cirler was especially close to Erastus and backed his resistance. Even the Count Palatine Johann Casimir, who frequently engaged in military efforts on behalf of the French and Dutch Protestants, rejected the disciplinists' aims. When one surveys the impressive support the anti-disciplinists possessed, it is not difficult to understand how confident they were that the elector would not make any radical innovations. ${ }^{123}$

The storm over church discipline raged through the summer and into the fall of 1568 in Heidelberg. By October an effort was underway to suppress the controversy. A letter from Erastus to Elector Frederick recounts an effort to confiscate the transcriptions of his theses in the students' possession. Alarmed that he was being portrayed as the troublemaker, Erastus defended himself by explaining the evolution of the controversy. He asked rhetorically why he should not be able to write, since he only sought the truth in harmony with the Scriptures. Erastus reported that he had sent the theses to Bullinger and Beza for their judgment but that he had not distributed them widely. However, the theses had circulated farther than he had realized. He belatedly sent an exemplar to Frederick, when he learned that a copy had made it into the elector's hands without his preface. Erastus mooted his intention to translate the theses into German so the prince could see for himself their mildness and scriptural integrity. Erastus entreated the elector not to believe that he sought to stir up dissention with the theses but that he had only sought the truth in humility. ${ }^{124}$

Apparently Erastus's effort succeeded in preventing his work from being confiscated, but he could not halt the effort to limit public debate on excommunication. With the elector's blessing, the theology faculty of the university took action to quiet the situation on October 14, 1568 by disallowing faculty from outside disciplines from taking part in theological disputations. This is sometimes described in the literature as the

${ }^{123}$ Press, Calvinismus und Territorialstaat, 249; Benrath, "Die Korrespondenz zwischen Bullinger und Thomas Erastus," 119; Wesel-Roth, Thomas Erastus, 60.

124 Erastus to Friedrich, Oct, 6. [1568]. The letter exists in two copies: Heidelberg, Universitätsbibliothek, MS Cod. Pal. germ. 839, fols. 62-63 and Karlsruhe, GeneralLandesarchiv, Kopialbuch 961, fols. 108-114. Both manuscripts are apparently scribal copies, though the Heidelberg exemplar has a brief postscript in Erastus's hand. 
prince's "hofbefehl" or at other times "silence order" on the question of church discipline, though it is not manifestly clear how extensive this injunction was. ${ }^{125}$ Accepting this directive went against the grain of normal university politics, as universities strove to preserve their liberties from princely interference. The senate's protocol indicates a fair amount of discord over the proposed limitation. The rector equivocated on the policy, declaring: "No one was to mix themselves in theological disputations, unless to the extent that the laws permit it, and if perhaps some ambiguity should arise in these things, the judgment of the prince may be sought." 126 From Erastus's perspective, it was a completely illegitimate and one-sided policy, as the disciplinists, who largely controlled the pulpits, evidently felt empowered to address discipline in their sermonsthough not beyond certain limits, as we will see. From Erastus's later correspondence it seems clear that this prohibition was either taken to mean that all public debate of controversial theological topics should cease, or that later a more extensive electoral order was issued effectively demanding silence on the church discipline question. ${ }^{127}$ In any event, early modern governments had limited tools at best to suppress the exchange of ideas, and the jockeying for position between the parties continued, though in a more muted fashion.

Around the time efforts were being made to quash the controversy in Heidelberg, information about the dispute was streaming to Zurich, Geneva, and other Reformed communities. Erastus had sent copies of his theses to Bullinger, Johannes Haller in Bern, and, eventually, Beza that fall. He received a very warm response from Bullinger which did

125 UAH, A-160/9, fols. $88^{\mathrm{v}}-89^{\mathrm{r}}$. Excerpts with analysis in Winkelmann, Urkundenbuch der Universität Heidelberg, 2:131. See Wesel-Roth, Thomas Erastus, 55; Horn, "Johann Sylvan," 253; Hautz, Geschichte der Universität Heidelberg, 2:79-81; Benrath, "Die Korrespondenz zwischen Bullinger und Thomas Erastus," 115-116; Burchill, "Die Universität zu Heidelberg," 241.

$126 \mathrm{UAH}, \mathrm{A}-160 / 9$, fol. $89^{\text {r: }}$ "Tandem post multam disceptationem M.D. Rector ad hunc modum interloquibatur: probo ne quis disputationibus theologicis se misceat, nisi quatenus legibus id permittitur, et si quae forte in iis oboriatur ambiguetas, iudicium illustiss. principis requiratur."

${ }^{127}$ Erastus mentions a specific prohibition by the elector against distribution of his theses in a letter to J.J. Grynaeus, March 20, [1570], Basel UB, G II 4, fols. 279-280. The Schaffhausen student Johann Jetzler had sent a letter home to Konrad Ulmer saying: "Interea, dum haec geruntur, hac de controversia est in schola et Ecclesia silentium: quonium utrique parti imperavit Elector." Dec. 10, 1568, quoted in Horn, "Johann Sylvan" 253 (in note). See also Erastus to Bullinger, April 9 and 18, (15)71, quoted below in note chapter 7 , note 53 . 
not necessarily endorse the extremes of Erastus's position, but let Erastus know in no uncertain terms that the Zurich theologians supported him. ${ }^{128}$ Erastus would not find a sympathetic hearing in Geneva. Beza had evidently already seen the original version of the theses, apparently sent to him by Withers himself. ${ }^{129}$

While the controversy temporarily cooled, or at least began to move underground in Heidelberg into the winter of 1569, it was only beginning on the international level. Erastus complained that the elector's effort to silence the controversy was being used to the advantage of his opponents. Boquin, Ursinus, and Zanchi had all put forward counterarguments to Erastus's theses. ${ }^{130}$ Neuser may also have contributed a report on church discipline to the elector, and Sylvan composed his own treatise on excommunication, which appears to have been widely circulated within the Palatine church. ${ }^{131}$ Beza objected to Erastus's theses, and while Bullinger worked to influence the Palatine court, he also sought to ease the tension between Erastus and Beza. ${ }^{132}$ Beza was exasperated with Erastus, as he revealed in a letter to Bullinger: "Would that Erastus would

128 Bullinger to Erastus, Zurich, Oct. 17, 1568. Explicatio gravissimae quaestionis, 350351: "A postremis verò meis ad te datis, mox accepi Theses tuas, insuper \& Tractationem de Excommunicatione. Legi, \& avidè quidem. Dedi legenda D. Wolphio, Lavatero, Hallero, Zuinglio, \& imprimis Gualthero, \& Simlero \&c. Placent illa nobis. Neque enim existimamus negotium coenae Dominicae implicandum huic negotio. Diu cum Anabaptistis nostris contendimus hac de re, ostendimus Ecclesiam veram posse esse, et dici Ecclesiam, quae excommunicatione hac careat. Rursus tamen contendimus disciplinam esse debere in Ecclesia, ac satis esse, si ea administretur à magistratu. Interim nunquam damnavimus Ecclesiam Genevensem, quae suam habet disciplinam. Nos si talem inducere vellemus in nostras Ecclesias, perderemus certò has citius, quàm servaremus. Vide quid in Confessione nostra hac de re scripserimus. Sentimus nos praeterea vobiscum, non facere ad aedificationem Ecclesiarum Palatinatus, neque ère vel bono fore Principis, si talis instituatur disciplina, id iest, Excommunicatio, qualem nonnulli volunt: quos optaremus diligentius apud se expendere illud Apostoli: Data est mihi potestas ad aedificationem, non destructionem \&c. Multa sanè sunt hic, maximè exulceratissimo hoc tempore consideranda. Breviter, tecum, mi Domine, \& frater, sentimus. Multum haec caussa nos exercuit."

${ }^{129}$ Beza to Bullinger, Oct. 31, 1568, CB, 9:180-183: "Scripsit ad me non ita pridem D. Erastus, se commentatum esse quaedam de excommunitione, quae brevi esset ad me missurus. Paulo post ecce quasdam ad me theses, numero centum et amplius, ad me mittit Heydelberga studiosus quidam Anglus, nullo addito nec edito scriptoris nomine. Eas quum in manus sumpsissem, statim Erasti esse conjeci, sed perlegere non potui, adeo mihi ab ipso initio displicuerunt."

${ }^{130}$ Erastus to Bullinger, Feb. 2, 1569, StAZ, E II 346a, fols. 549-550. In this letter Erastus also notes that Beza is contemplating a response, though Erastus doubts that he will follow through with it.

131 Burchill, The Heidelberg Antitrinitarians, 123 (for Neuser), 71 (for Sylvan).

132 Bullinger to Beza, March 13, 1569, CB, 10:55-57 (no. 661): "Perge tu vere fraterne 
be content to dissent concerning the use and need of excommunication, but not to overthrow the thing itself, contriving it to be a human thing or also a tyranny." 133

After some months Beza likewise responded to Erastus's theses. This manuscript would eventually appear under the title Pious and Moderate Tract concerning True Excommunication and the Christian Presbytery (Tractatus pius et moderatus). Evidently Beza was in no hurry to send the tract to Erastus. ${ }^{134}$ In September still Erastus "marveled that Beza had not sent it to him" despite the fact that Beza's response had been finished in July. ${ }^{135}$ Bullinger did receive Beza's repudiation of Erastus's views in late July. He was clearly distressed by Beza's tract and asserted that he did not want to see it published but hoped to keep the disagreement private. While responding diplomatically to Beza, Bullinger lamented that the question of discipline had become tied to the Lord's Supper and also bemoaned the influence of Netherlandish exiles in the Palatinate. ${ }^{136}$ Erastus would not see Beza's response until November of 1569, and he accused Beza of bad faith in withholding his rebuttal. Beza attempted to explain his actions, citing the need to first vet his work with his colleagues and his desire not to further inflame the Heidelberg scene by making his rebuttal widely available. Beza extended a hand of friendship to Erastus, but also implored him to stay within the limits of his own profession,

cum D. Erasto conferre. Scio esse qui frigidam suffundunt. Sed ne audieris tales. Dominus bonae causae non deerit, si modeste et prudenter agamus. Deus dissipet contentiones et dissidia."

${ }_{133}$ Beza to Bullinger, August 8, 1569, CB, 10:151-153 (no. 692): "Utinam Erastus noster contentus fuisset de usu et necessitate excommunicationis disserere, non autem rem ipsam convellere, quasi humanum aut etiam tyrannicum commentum, quod ita esse nunquam illi concedam, nisi longe firmiora protulerit argumenta."

134 Theodore Beza, Tractatus Pius et Moderatus de vera Excommunicatione, \& christiano Presbyterio ... (Geneva: Jean Le Preux, 1590); Beza to Bullinger, July 25, 1569, CB, 10:134-135 (no. 685). "Respondi ad D. Erasti Theses, et responsum Heidelbergam misi, quod curabo etiam tibi describendum. Neque id, ut spero, tibi caeterisve fratribus displicebit." Beza had, however, made his opinion known to Erastus in a letter prior to April, 1569. Erastus to Bullinger, April 13, [1569], Zurich, Zentralbibliothek, MS F 62, fol. 203. For an analysis of the Tractatus, see Tadataka Maruyama, The Ecclesiology of Theodore Beza: The Reform of the True Church [THR 166] (Geneva: Droz, 1978), 108-122. The publication of Beza's Tractatus is discussed in the epilogue below.

135 Jan Lasicki to Beza, Sept. 22, 1569, CB, 10:193-195.

136 Bullinger to Beza, August 1, 1569, CB, 10:140-141 (no. 687): "Legam libenter quae respondisti ad Theses nostri Erasti. Nollem ego publicata esse spero privato te scripto ista agere.... Mea quidem sententia potest in Ecclesia justa contitui disciplina, ut interim Coena Domini libera maneat omnibus illis, qui juxta Pauli doctrinam probarunt, neque convertatur in poenam." 
and thus to withdraw from the church discipline discussion. ${ }^{137}$ Erastus by no means gave Beza's response a sympathetic reading and wrote back what can only be described as a howler of a letter savaging Beza for the emptiness of his self-justification. Given the fact that Beza had earlier enjoined him to keep this a fraternal discussion, Erastus was particularly galled that Beza had not directly communicated with him, the very person with whom he had a difference of opinion. While Erastus was thus robbed of the potential benefit from Beza's fraternal censure, Beza had "armed his enemies against him." Erastus boldly proclaimed that he found Beza's refutation lame and also marveled at how much the champions of presbyterial oversight disagreed with one another. He informed Beza that he would refute his tract and that he would concentrate on separating the spheres of civil and ecclesiastical authority. In fact, Erastus must have already completed his Confirmatio thesium, the bulk of which was a response to Beza's critique, a couple of weeks prior to writing this letter. Though Beza repeatedly sought to reconcile with him, Erastus would spurn these gestures for over a decade. ${ }^{138}$

While Erastus and Beza penned the most prominent theological works in the controversy, the leaders of the Zurich church also attempted to influence the Heidelberg conflict. Bullinger and the Zurichers entered the fray on the anti-disciplinist side by sending two direct appeals to the Elector Frederick himself and addressing the issue at the core of the controversy in a number of theological works. ${ }^{139}$ The Zurich opinion found little purchase with the disciplinist leaders who were now driving Palatine religious policy. Nevertheless, the leaders of the Palatine church wanted to maintain good relations with the Swiss Germans, and

137 Beza to Erastus, December 18, 1569, CB, 10:245-247. Clearly Erastus and Beza exchanged multiple letters in 1568 as is revealed in Beza's correspondence with Bullinger and in Beza's preface to his Tractatus pius et moderatus de vera Excommunicatione (see below). Ironically the only letter which has been preserved from that year is Beza's essaytype letter to Erastus concerning astrology.

${ }^{138}$ Erastus to Beza, January, 1570, CB, 11:29-35: "Nunc cum adversarios meos armasti, et tela illa tua mihi ignota esse voluisti, re ipsa confutas quae verbis affirmas. Verisimile est alia fuise agitata consilia, de quibus me iam pridem aliquid audivisse non ignoras. At Deus videt iniustos hominum conatuas, nisi cum eis abuti statuit ad suam gloriam suorumque salutem. Cur, cum mittebas non duobus verbis seu dimidio verus mihi indicabas quod to iam innanibus verbis frustra studes excusare?" Erastus discusses receiving Beza’s response and commencing his Confirmatio thesium in a letter to Bullinger, Nov. 21, 1569, StAZ, E II 361 , fol. 77 . Their eventual reconciliation is discussed in the epilogue.

139 The letters are printed in Stimmen aus dem Schweizerischen Reformationszeitalter über die Exkommunikation oder den Kirchenbann (Bern: Hallersche Buchdruckerei, 1839). See Wesel-Roth, Thomas Erastus, 57-58; Bonnard, Thomas Éraste, 160-166. 
dispatched Zuleger on a diplomatic mission to Zurich and Bern in early 1569 to make them more amenable to the disciplinist program. The mission was not surprisingly a flop, as can be discerned from the contemporary correspondence of Bullinger in Zurich and Haller in Bern, and relations between Heidelberg and the Swiss Germans soured markedly. Dathenus also endeavored to separate Bullinger from his attachment to Erastus and his "impious paradoxes." 140 In the meantime, the Heidelberg Calvinists began to repudiate their Zwinglian allies, and even prohibited the publication of Bullinger's Decades in Heidelberg due to the alleged theological errors it contained. ${ }^{141}$ Not surprisingly, Zurich and Bern remained behind Erastus. Bullinger composed a strident response to Dathenus later in 1570, which may be the most remarkable document of the church discipline controversy. In it he outlined the long continuity of the Zurich-Bern position on church discipline and threw his weight solidly behind Erastus. Given Erastus's known contribution to the Palatine Reformation, Bullinger rebuked Dathenus for not treating Erastus in a more collegial manner. While Bullinger sided with Erastus, he nevertheless did not explicitly endorse Erastus's complete repudiation of excommunication. ${ }^{142}$ The letter left Dathenus both stung and perplexed. Dathenus described the letter to Beza as being "gentle and friendly" but not lacking "teeth and spines." Dathenus seemed to fathom Bullinger's position but resented what seemed to be the Zurich effort to "judge" the Palatine church. It continued to bemuse Dathenus that Bullinger was defending Erastus so doggedly given the significant gap in their perspectives, as he commented: "I don't know how it is possible to reconcile his opinion with Erastus's theses." 143 Throughout the 1560s the Zurich church had been a chief source of support and council for the Heidelberg Reformed, but this close connection evaporated in the discipline controversy. The Heidelberg repudiation of the Zurich legacy echoed abroad; the synods of La Rochelle and Emden endorsed the organization of the Dutch and French churches along more explicitly Calvinist lines. ${ }^{144}$

\footnotetext{
140 Dathenus to Bullinger, May 9, 1569, quoted in Bonnard, Thomas Éraste, 61.

${ }^{141}$ Erastus to Bullinger, May 22, [1569], StAZ, E II 361, fol. 38: "Clàm dehortantur quos possunt ab emptione Decadum hic excusorum quia tres magni in eis errores habeantur: de praedestina[tione], de descensu Christi ad inferos: de disciplina Ecclesiastica."

142 Bullinger to Dathenus, June 1, 1570, printed in Explicatio gravissimae quaestionis, 355-367. See Benrath, "Die Korrespondenz zwischen Bullinger und Thomas Erastus," 122.

143 Dathenus to Beza, Nov. 5, 1570, CB, 11:290-294 (no. 809): "Caeterum, quomodo ille suam sententiam cum Erasti thesibus conciliare possit, non video."

${ }^{144}$ Discussed more fully in the epilogue.
} 
In the summer and fall of 1569 , despite the fact that the attempt to institute consistorial oversight had little popular support, the disciplinists had already won over the elector and were moving ahead with plans to institute their system. ${ }^{145}$ In the midst of this bitter controversy Erastus slipped out of town to celebrate his sister-in-law Lavinia's marriage with Johann Jakob Grynaeus, the brother of his close friend Simon Grynaeus. This match ended up solidifying a very productive alliance between the two families. Upon Erastus's return, he found the city in a state of excitement over a recent sermon by Olevianus on the story of Jesus and the ten lepers from Luke 17. In this passage, after healing the lepers, Jesus had enjoined them to "Go and show yourselves to the priests" to demonstrate that they had been healed and thus made ritually clean. According to Erastus's rather colored account, Olevianus had used this passage as a proof text to establish the principle that "ministers have the authority to exercise judgment over morals." Evidently the spectacle was so extreme in length and acerbity that Olevianus was brought before the prince's council, where he was admonished to act with greater prudence. ${ }^{146} \mathrm{~A}$ week later Erastus recounts Olevianus made another unpleasant public scene with the Chancellor Prob and his son-in-law Gerhard Pastoir and accused Prob of discrediting him with the prince. Erastus commented that people were beginning to question Olevianus's sanity, and assessed, with no little Schadenfreude, that "what it has taken him eight or nine years to build, he has torn down completely with one sermon."147

\footnotetext{
${ }^{145}$ Erastus to Bullinger, July 8, (15)69, StAZ, E II 346a, fol. 551v: "Adversarii nostri apud Principem videntur obtinere quod volunt: ii tanto odio flagrant in omnes illos, quos cupiditati suae opinantur resistere velle, ut à sceleratis artibus non abstineant, quo calumniis, metu, terrore, minis obruant, quos causa vincere nequeunt.... Consiliarii omnes, nobiles, ignobiles, populus, aula, adversantur: illi tamen fortiores sunt omnibus. Dicuntur collecturi principio manum, et ex illa electuros seniorem unum aut duos: accedentibus aliis, plures. Cogent autem accedere hoc modo. Non patientur alios accedere ad Coenam: nec baptizabunt liberos suos cuiquam, nisi prius promittat se coniuncturum se caetui suo sancto. Quid futurum sit nescio: boni nihil expecto." Later an exasperated Erastus wrote again to Bullinger concerning the disciplinists' minority position but overweening influence with the elector: "Non filios, Non Consiliarios, qui ei, uno excepto Ehemio, constanter adversantur omnes. Non nobiles, Non doctos, non plebeios aud[it]." Jan. 1, (15)70, StAZ, E II 361, fol. 17.

146 Jan Lasicki to Beza, Sept. 22, 1569, CB, 10:193-195 (no. 706): "Invectus est quidem Olevianus ante paucos dies in eos principis consiliarios qui rei tam laudatae resistunt, adeo ut lachrymas ex oculis concionantis manantes viderimus. Verum ea re non nisi animos illorum adversum se concitavit. Imprudentiae eum accusant, quod ignarus rerum in Palatinatu, id urgeat, quod fieri non possit, universa plebe omnino refragante."

147 Erastus to Bullinger, Oct. 10, 1569, StAZ, E II 361, fols. 16-16" : "Eteni[m] Olevianus, ut est impotentis ingenni homo et furiosi cereb[ri] .16. Sept. concionem habuit non ultra
} 
From Withers's promotion in 1568 into the winter of $1569-1570$, the Heidelberg church and community were riven with dissent over church discipline. Both camps had formidable supporters. To this point, though the disciplinists had the inside track with the elector, it seemed their highhanded and inept tactics might undermine the effort to institute consistorial discipline. Erastus even optimistically quipped that "Our excommunication will kill its mother in delivery, before it sees the light of day." 148 Ironically the indiscretions of the anti-disciplinists themselves in the coming year would create the context in which the disciplinists would be given a free hand to remake the Palatine church.

quartam horae partem, de 10. leprosis, volens ex eo probare, Ministros habere potestatem exercendi iudicia de moribus. Hac re valde pertubati auditores, ut qui scirent eum nunquam ferè minus sesquihora $\mathrm{c}[\mathrm{on}]$ cionari, varie fuerunt affecti. Admonitus Princeps, qui iam paratus erat exire ad venationem, vocatum ad se obiurgavi[t.] Sequenti Dominica in cathechistica concione, conversus, ad Cancellarium eiusque generum, palam conquestus est immani clamore et ululatu mendaciis se ab ipsis apud principem deformatum: et ita in illos debacchatus dicitur, ut nunquam sic in Verrem Cicero dixissem putetur. Existimant omnes eum non fuisse mentis compotem, ita foedè et turpiter egisse dicitur. Certè, si quid his octo novemve annis aedificavit, una illa concione totam destruxit." See Hollweg, Neue Untersuchungen, 1:140; Wesel-Roth, Thomas Erastus, 60; Press, Calvinismus und Territorialstaat, 120.

148 Erastus to Bullinger, Jan. 24, [1570] StAZ, E II 361, fol. 33: "Nostra excommunicatio enecabit, puto, matrem suam parturientem antequam in lucem prodeat." 